\title{
GEOLOGY, AIRBORNE GEOPHYSICS, GEOMORPHOLOGY AND SOILS IN THE INDIVIDUALIZATION OF THE NIQUELÂNDIA MAFIC-ULTRAMAFIC COMPLEX, GOIÁS STATE, BRAZIL
}

\author{
Inara Oliveira Barbosa ${ }^{1}$, Augusto Cesar Bittencourt Pires², \\ Marilusa Pinto Coelho Lacerda ${ }^{3}$ and Adriana Chatack Carmelo ${ }^{4}$
}

\begin{abstract}
The airborne geophysical data allow the characterization and individualization of thick soils developed from a particular geological substrate. This work uses Gamma spectrometry and magnetic data, along with relief, soil classes and geology to characterize and individualize the Niquelândia Mafic-ultramafic Complex and its adjacent units. The database was created with georeferenced information available on geology, geomorphology and soil. The relief features were generated using the Digital Terrain Model (DTM) obtained with the data extracted from the Shuttle Radar Topography Mission (SRTM). The data generated maps of slope and hypsometric classes. The airborne geophysical magnetic and Gamma spectrometry data were extracted from the Goiás State, Brazil, airborne geophysical survey for the "Northeastern Paleo-Neoproterozoic Goiás" Project. These data were interpolated using minimum curvature method for the Gamma spectrometry data (K, U and Th) and bi-directional data for the magnetic. The anomalous magnetic field data were used to obtain the Analytical Signal Amplitude (ASA), and from ASA together with the Gamma spectrometry data, the Mafic Index (MI) was calculated. The MI has allowed a better delineation of mafic and ultramafic bodies without soil influence. The correlation with the airborne geophysics, geology, topography and soil allowed characterizing and individualizing the Niquelândia Mafic-ultramafic Complex and adjacent geological units, consisting of different lithologies. The result shows the efficiency of the Mafic Index in the discrimination of Mafic-ultramafic rocks, as it eliminates the surface magnetic response, originated of altered rocks and soils, and highlights the magnetic response of the subjacent rocks.
\end{abstract}

Keywords: airborne geophysics data, hypsometric, weathering, Niquelândia Complex.

RESUMO. Os dados aerogeofísicos permitem a caracterização e individualização de rochas de composição geoquímica distinta, material intemperizado e solos espessos desenvolvidos a partir de um determinado substrato geológico. Desta forma, podem auxiliar a caracterização e distribuição de depósitos minerais de origem pedogenética. Assim, o objetivo deste trabalho foi a utilização de dados magnetométricos e gamaespectrométricos, juntamente com a caracterização da geologia, do relevo e das classes de solos na caracterização e individualização do Complexo Máfico-Ultramáfico de Niquelândia e suas unidades geológicas adjacentes. Foi criado um banco de dados georreferenciados com informações disponíveis sobre a geologia, geomorfologia e solos. As feições geomorfológicas foram geradas por meio do Modelo Digital do Terreno (MDT) obtido a partir dos dados do Shuttle Radar Topography Mission (SRTM), sendo dele derivados os mapas de classes declividade e de classes hipsométricas da área de estudo. Os dados aerogeofísicos de magnetometria e gamaespectrometria foram extraídos do levantamento aerogeofísico de Goiás do Projeto "Paleo-neoproterozóico do Nordeste de Goiás". Estes dados foram interpolados utilizando o método mínima curvatura para os dados da gamaespectrometria (K, U e Th) e bidirecional para os dados de magnetometria. Com o processamento dos dados gamaespectrométricos foram individualizados dezenove domínios, com variações nos valores de $\mathrm{K}$, eU e eTh, relacionados à composição geoquímica das unidades geológicas, além do relevo e classes de solos. Com os dados magnetométricos foram elaborados o Campo Magnético Anômalo e a Amplitude do Sinal Analítico (ASA). A partir da Amplitude do Sinal Analítico foram separados cinco domínios magnetométricos que demonstraram a variabilidade litológica e de classes de solos da área estudada. A partir do produto ASA juntamente com os dados gamaespectométricos foi calculado o Índice Máfico (IM), cuja espacialização permitiu a delimitação dos corpos máficos e ultramáficos do Complexo de Niquelândia sem a influência do solo. A correlação com os dados aerogeofísicos, geológicos, relevo e classes de solo permitiu interpretar, caracterizar e individualizar o Complexo Máfico-Ultramáfico de Niquelândia das suas unidades geológicas adjacentes, constituídas por litologias distintas. Tal resultado mostra a eficiência do Índice Máfico na discriminação de rochas máficas-ultramáficas, visto que este elimina a resposta magnética superficial, decorrente de rochas alteradas e solos, e ressalta a resposta magnética da rocha subjacente.

Palavras-chave: dados aerogeofísicos, hipsometria, intemperismo, Complexo de Niquelândia.

\footnotetext{
1 Departamento Nacional de Produção Mineral, Edifício Sede, S.A.N. Quadra 1, Bloco B, sala 105B, Asa Norte, 70041-903 Brasília, DF, Brazil. Phone: +55(61) 33126875; Fax: +55(61) 3312-6920 - E-mail: inara.barbosa@dnpm.gov.br

${ }^{2}$ Universidade de Brasília, Instituto de Geociências - IG, Departamento de Geoquímica e Recursos Minerais, Asa Norte, 70910-900 Brasília, DF, Brazil. Phone: +55(61) 3340-4759; Fax: +55(61) 3340-4759 - E-mail: acbpires@unb.br

3 Universidade de Brasília, Faculdade de Agronomia e Medicina Veterinária, Instituto Central de Ciências, Asa Norte, 70910-900 Brasília, DF, Brazil. P.0. Box: 4508, Phone: +55(61) 3307-2823, Extension: 16; Fax: +55(61) 3273-6593 - E-mail: marilusa@unb.br

${ }^{4}$ Universidade de Brasília, Instituto de Geociências - IG, Asa Norte 70910-900 Brasília, DF, Brazil. Phone: +55(61) 3307-2862; Fax: +55(61) 3340-4759 - E-mail: chatack@unb.br
} 


\section{INTRODUCTION}

The use and integration of data from various sources have assisted geological mapping and modeling related to the distribution of mineral deposits. However, when mineralization involves weathering processes, models must also take into account geomorphology and pedology, besides the geological features, resulting in a more complete and individualized model for each specific case. Recently, studies to generate models and methods that contribute to the characterization of rocks and weathered materials have been using airborne geophysical and remote sensing data (Souza Filho \& Crósta, 2003; Teixeira et al., 2006; Carrino et al., 2007).

Geophysics has brought great benefits to research in tropical regions such as Brazil, where supergene processes lead to the formation of thick soils and vegetation that hinder access to geological substrate information (Souza Filho \& Crósta, 2003).

Besides identifying geological units, airborne geophysics data can also assist in mapping soils, mineral deposits and geological structures. According to Pires (1990) the result of the integration of gamma ray spectrometric and magnetic data correlated well with those obtained from the geological maps.

Studies integrating data from different sources can subsidize the strategic planning of the Brazilian mining sector. The integration of multi-thematic digital geospatial data (geology, geomorphology, airborne geophysics and remote sensing) have been used in geosciences studies. Searching for spatial correlations using various types of data with the aid of geo-technologies have proven very effective in getting detailed geological information (Raines \& Bonham-Carter, 2006; Nykänen et al., 2008; Eddy et al., 2010).

The Mafic-Ultramafic Complexes of Niquelândia, Cana Brava and Barro Alto constitute important units in the Brazilian geological context due to the occurrence of mineral deposits where the mineralization results from supergene enrichment processes. Thus, the spatial modeling of these deposits involves integration of geology, pedology and geomorphology data. However, there are no such studies which allow spatial characterization and individualization of these complexes (Dickson \& Scott, 1997). Regional studies, using low-resolution aeromagnetic data, showed a similar geophysical response for the mafic-ultramafic complexes of Goiás (Blum, 1999). According to the literature, the Niquelândia Complex presents low response for the concentrations of the three radioelements while it is defined by positive magnetic lineaments (Blum, 1999).

Magnetometry allows mapping Fe-rich lithologies whereas gamma spectrometry shows the distribution of $\mathrm{K}, \mathrm{U}$ and $\mathrm{Th}$ that are elements directly related to the mineralogical compositions of both rocks and soils. The use of gamma spectrometric and magnetic data contribute for geological mapping and to the studies of distribution of primary and pedogenic origin mineral deposits

Within this scenario, the subject of this study was to correlate airborne gamma ray spectrometry and magnetic data, along with geology, soil and relief information, to individualize the Niquelândia Mafic-Ultramafic Complex, GO from its adjacent geological units

\section{Study Area Characterization Location}

The study area comprises the layered Mafic-Ultramafic Complex of Niquelândia and its adjacent geological units, located in the municipality of Niquelândia, Goiás State, Brazil. (Fig. 1).

\section{Geological Context}

The Mafic-Ultramafic Complex of Niquelândia and its adjacent units are inserted in the Tocantins Province (Mantovani \& Brito Neves, 2005), the extensive orogenic-collisional, neoproterozoic age, that was generated between the cratons of Amazon (passive margin), San Francisco/Congo and Parapanema (active margin) According to Pimentel et al. (1991), Pimentel \& Fuck (1992) and Fuck et al. (2006), the Province is divided into three supra-crustal folded belts known as Araguaia, Paraguay and Brasilia strips.

The Mafic-ultramafic Complexes of Cana Brava, Niquelândia and Barro Alto are highlighted in the northern portion of the Tocantins Province (Hasui \& Almeida, 1970).

In the center-north portion of the Tocantins Province, where the city of Niquelândia is located, two geotectonic units occur: Massif of Goiás and the Brasilia Belt (Fuck, 1994). In addition to the Niquelândia Complex, the geological units of the Massif Goiás, represented by the Serra da Mesa Group and the VolcanoSedimentary Sequence of Indaianópolis are also located in the study area. This geological setting is formed by basement units covered by the neoproterozoic meta-sedimentary rocks belonging to the Paranoá Group (Fig. 2).

The Mafic-Ultramafic Complex of Niquelândia has an oval shape, marked by faults and approximately $45 \mathrm{~km}$ along the N10E direction. It has been the subject of many studies over the years, since Pecora \& Barbosa (1944). During this period many hypotheses have been raised about the origin of the complex being the most controversial the layered mafic-ultramafic sequence, according to Motta et al. (1970, 1972), Danni \& Leonardos (1978) 


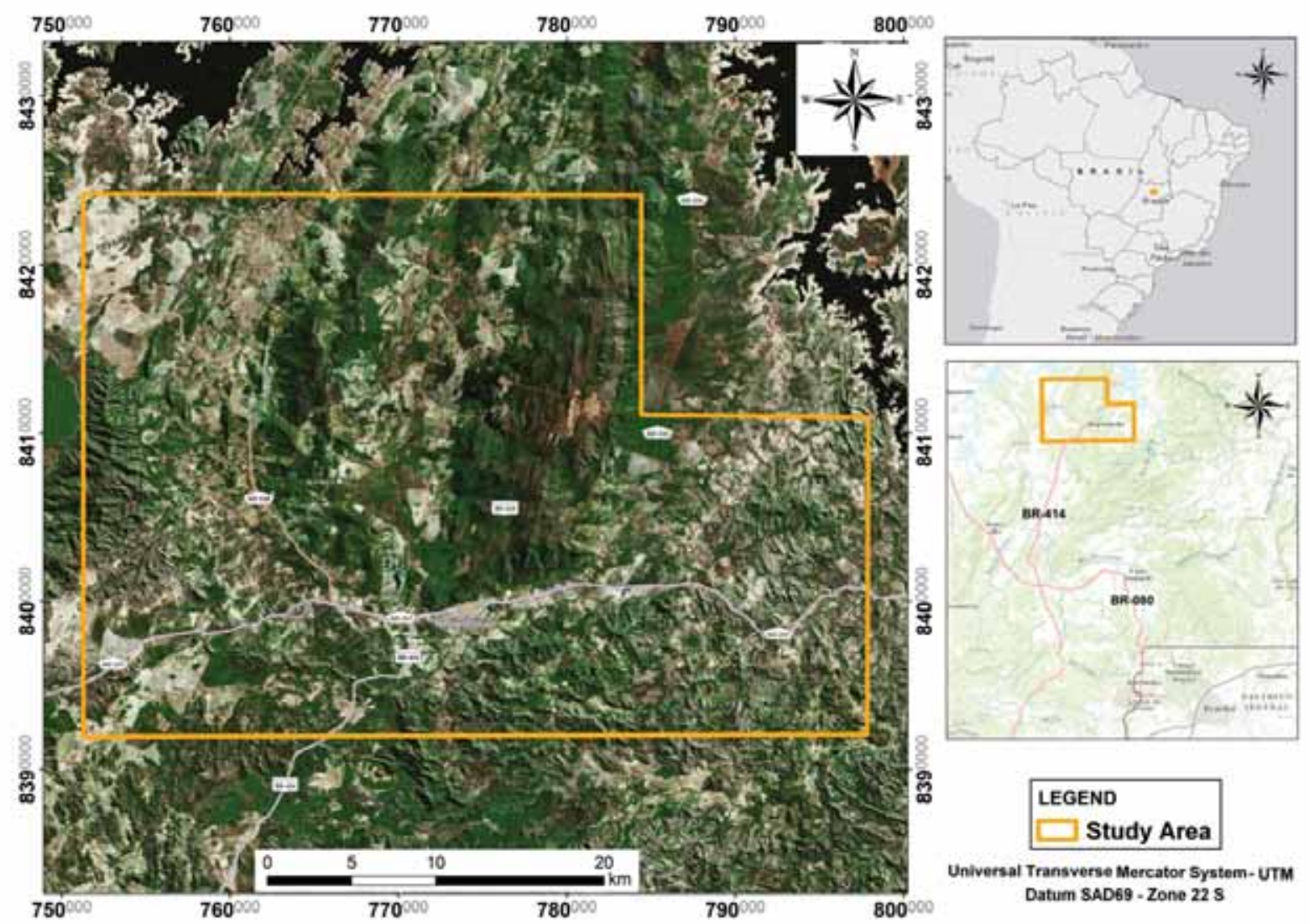

Figure 1 - Map of Location of the study area. Source: Image Spot 5 (Google Earth, 2013).

Danni et al. (1982), Rivalenti et al. (1982), Girardi et al. (1986), Ferreira Filho et al. (1992, 1994), Ferreira Filho \& Naldrett (1993), Brito Neves et al. (1995), Correia et al. (1996) and Pimentel et al. (2004). Among the various controversial interpretations regarding the origin of the complex, one can refer the study of Girardi et al. (1986), who considers it a single intrusion formed from the same parental magma. The study conducted by Ferreira Filho et al. $(1994,1998)$ reports the existence of two sets of petrologically distinct cumulatic rocks.

According to Correia et al. (1996, 1997, 1999), Ferreira Filho \& Pimentel (1999) and Medeiros \& Ferreira Filho (2001), the Niquelândia Complex consists of:

A) Lower Magmatic Sequence (Serra da Mantiqueira Unit) divided in three zones: i) Lower Mafic Zone, consists predominantly of gabbronorites with secondary levels of pyroxenite; ii) Intermediate Ultramafic Zone, essentially composed of dunites interspersed with pyroxenite; and, iii) Upper Mafic Zone, dominated by gabbronorites, with quartz-diorite intrusions; and

B) Upper Magmatic Sequence (Serra dos Borges Unit) formed by interbedded leuco-troctolites, anorthosites, gabbros and olivine gabbronorites with subordinate pyroxenite and levels of Fe-Ti oxides (magnetite and ilmenite).

The Paleoproterozoic basement corresponds to Rio Maranhão Complex, consisting of granite-gneiss lithologies of dioritic composition (Almeida et al., 2006).

The Volcano-Sedimentary Sequence of Indaianópolis (Danni \& Leonardos, 1980; Nascimento et al., 1981) consists of remnants of Mesoproterozoic ocean crust (1.2 Ga.). Pimentel et al. (2000) and Souza Neto \& Leon (1998) considered this sequence divided into two subunits:

i) Lower Sequence comprises fine amphibolites interbedded with biotite-schist, biotite-gneiss, metacherts and banded iron formations, and

ii) Upper Sequence is composed of rhyolites and rhyolitic tuff, schist, quartzite, fine amphibolite and metacherts.

The Mesoproterozoic Paranoá Group, 1350-950 Ma. (Dardenne, 1978; Faria \& Dardenne, 1985; Faria \& Dardenne, 1995) is subdivided into ten mapped units distributed in two main sequences, psamo-pelitic at the base and psamo-peliticcarbonate at the top. The tectonic and metamorphic processes 


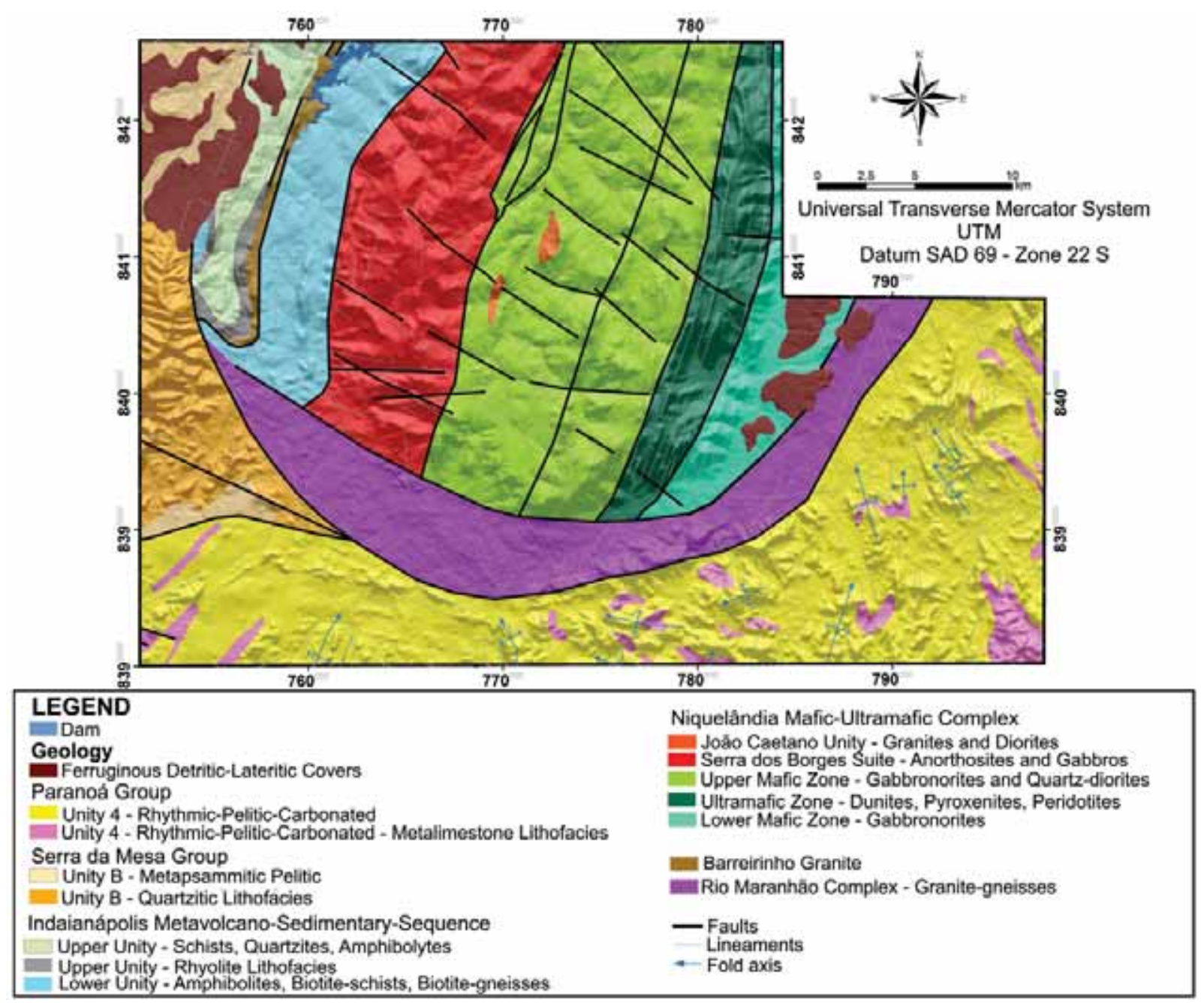

Figure 2 - Geological map of the study area (Source: Moreira et al., 2008).

occurred during the Braziliana orogenesis, peaking between 0.65 and 0.60 Ga. (Fuck et al. 1988; Pimentel et al. 1999).

According to Marini et al. $(1977,1984)$ the Serra da Mesa Group consists of sedimentary Paleo/Mesoproterozoic rocks, comprising quartzites at the base, followed by mica-schist with garnet, staurolite and kyanite, with interbedded fine quartzites and, calci-shist lenses and marbles, with thickness of about 1500 m. According to Dardenne (2000), geochronological evidence indicates sediments deposition age between 1.6 and $1.47 \mathrm{Ga}$., in platform and continental environments arising from the rifts evolution.

The ferruginous lateritic-detritic unit shows up as the coverage of the northwestern and eastern portions of the studied area, which predominantly consist of thick soils with concentration of sesqui-oxides of iron and aluminum due to the high degree of evolution and iron content of the source lithology.

\section{Geomorphology}

They are scarce geomorphological studies in Goiás, especially regional mapping. RadamBrazil Project (1981) map at the scale $1: 1,000,000$ are the most used. The same basic methodology of the RadamBrazil Project (1981) was followed in further work done by Nascimento (1991) and Latrubesse \& Carvalho (2006), who recently presented the Geomorphology Project of Goiás and the Federal District, at scale of 1:500,000.

According to the article published by Mamede et al. (1981), the Mantiqueira and Borges chains of hills represent the Niquelândia Complex relief, reflecting a massive semicircular structure, whose high relief surrounds a more lowered central area. In these mountains, which form the western and eastern edges of the large structure of Niquelândia the altitudes range from 800 to $1,000 \mathrm{~m}$. 
According to Latrubesse \& Carvalho (2006) the units representing the geomorphology of the study area were named Regional Flatten Surfaces (SRA), Erosion Retreating Zone (ZER), Pseudo-domes (PSD), Mounts and Hills (MH) and folded structures forming Hogbacks (HB).

The Mafic-Ultramafic Complex Niquelândia consists of a sequence of layered intrusions, which under the geomorphological point of view is an example of Pseudo-domes (PSD), with around about $40 \times 15 \mathrm{~km}$.

\section{Soils}

The current soil map of Goiás, produced by the Hydrogeological Survey Project of Goiás, at scale of 1:1,000,000 (Almeida et al., 2006), classifies the soil in the area as Laterite-soils, represented by Red and Red-Yellow Laterite-soils, Entisoils and Cambisoils, and Ultisoils.

Laterite-soils are soils in advanced weathering stages, which are, therefore, deep and enriched with Fe and Al oxides and hydroxides. Generally, these soils occur in flat to undulated terrains.

Cambisoils are shallow soils placed in areas with steeper slopes, with maximum thickness of $50 \mathrm{~cm}$.

Ultisoils are soils with textural B-horizons, whose silicate mineralogy is represented by clay minerals of low activity. Soils are of variable depth, usually with rockiness.

Neosoils are little evolved soils where the characteristics of the origin material predominate and they are more common in rugged terrain areas.

\section{Materials and Methods}

The study was divided into three stages. The first stage consisted of defining the parameters to be used in the analysis and compila- tion of digital data. In the second stage, data processing was performed using the GIS techniques to produce a distribution map of the geophysical, magnetometric, slope and hypsometry data. The third and final stage consisted of correlating the generated maps.

The generated maps and the available geology map (scale 1:500,000; Moreira et al., 2008) were processed using the software ArcGIS 10.

\section{Processing of airborne geophysical data}

The data were extracted from the final report of the Area 5 of the Goiás state airborne geophysical (magnetic and Gamma spectrometry) survey, named "Paleo-Neoproterozoic Project of Northeastern Goiás" - Phase 2, conducted in 2006 by Lasa Engenharia e Prospecções S/A. (LASA, 2006). Survey characteristics are presented in Table 1.

The geophysical magnetic (total magnetic field) and gamma spectrometry (potassium, thorium and uranium channels) data were extracted from 2 files ASCII type (.GDB) and imported into the Oasis Montaj (Geosoft ${ }^{\circledR}$, 2009) software for generating of magnetic and Gamma spectrometry data distribution map, at scale 1:100,000.

After to import the airborne geophysical dataset the data were cut according to the study area followed by their evaluation. The gamma ray spectrometric data were already transferred as percentage for potassium (K); and ppm for uranium $(\mathrm{U})$ and thorium (Th), thus avoiding the transformation of counts per second (CPS).

The flowchart of the geophysical data processing is shown in Figure 3.

The gamma ray spectrometric database was homogenized for $K(\%)$ channel by adding a constant equal to $1 / 4$ of the standard

Table 1 - Technical information about the airborne geophysical survey.

\begin{tabular}{|l|l|}
\hline Methods & Magnetometry and Gamma spectrometry \\
\hline Contractor: & $\begin{array}{l}\text { State Government of Goiás/SIC-MME/CPRM } \\
\text { Geological Survey of Brazil }\end{array}$ \\
Contracted: & Lasa SA Engineering and Surveys \\
Period: & $05 / 01 / 2006$ to 09/01/2006 \\
Range (AM): & $0.1 \mathrm{~s}$ (magnetometry) and 1.0 s (Gamma spectrometry) \\
Flight height: & $100 \mathrm{~m}$ \\
Direction (FL): & $\mathrm{N}-\mathrm{S}$ \\
Spacing (FL): & $0.5 \mathrm{~km}$ \\
Direction (CL): & $\mathrm{E}-\mathrm{W}$ \\
Spacing (CL): & $5 \mathrm{~km}$ \\
Gamma Integration time & 1 \\
\hline
\end{tabular}




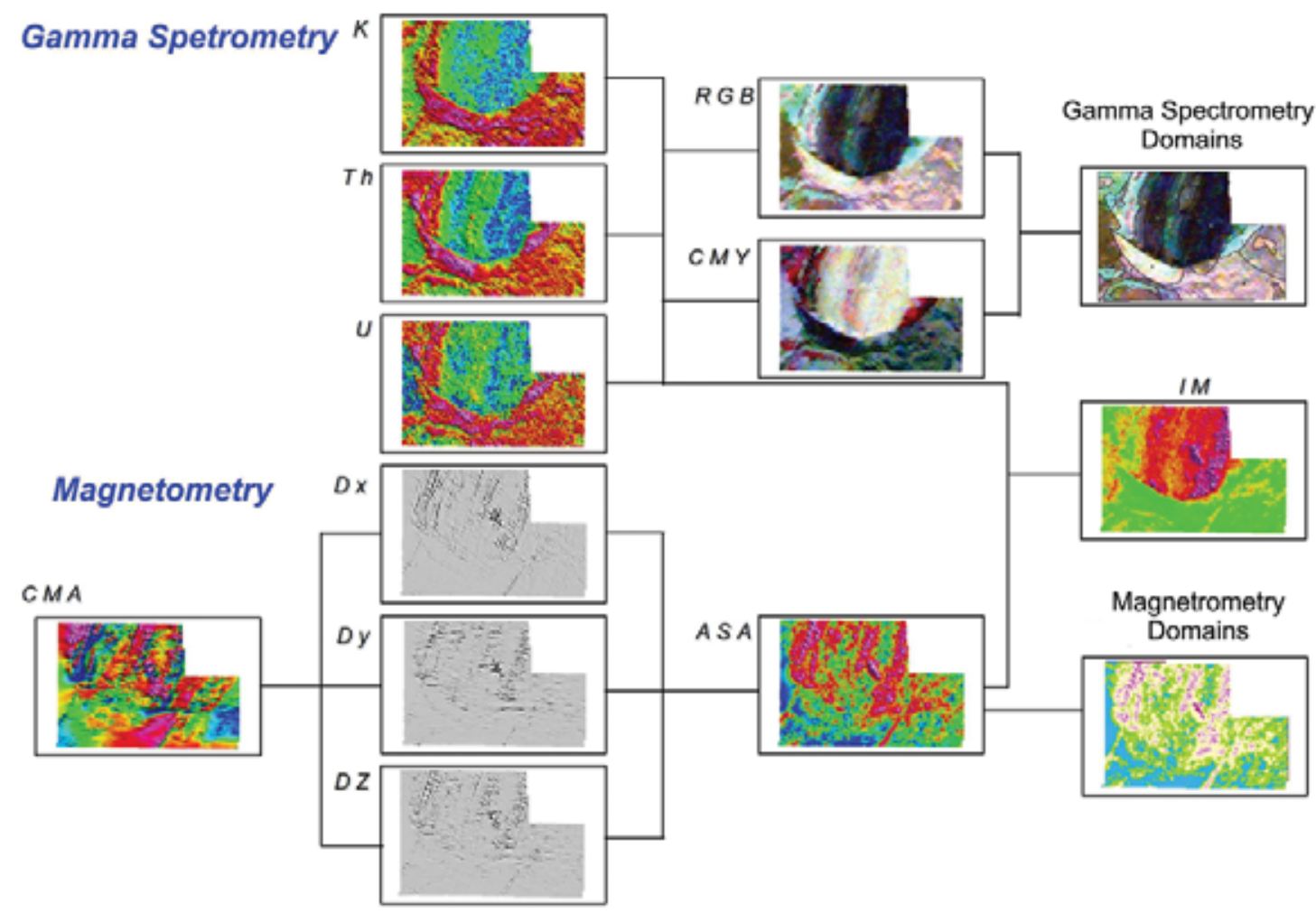

Figure 3 - Flowchart of airborne geophysical data processing.

deviation of this variable. The eU and eTh data were not modified. Data were corrected in order to approximate the mean values of radio elements to the contents of such elements in mafic rocks (about 1\% K; 0.7 ppm U; and 3 ppm Th) according to Dickson \& Scott (1997). The negative values of gamma ray data of K, eU and eTh were due to non-effective atmospheric correction and/or calibration of the instruments and they were abandoned.

The survey data were interpolated without using control lines, since the use of micro-leveling did not remove completely the "unlevelled" residues that still remained in the data.

Mesh cell size for interpolation of Gamma spectrometry data was set to $1 / 5$ of flight line spacing $(100 \mathrm{~m} \times 100 \mathrm{~m})$, to avoid information loss. The minimum curvature (Geosoft, 2009) interpolation method was chosen because it represents best the original data due to the fact that the geological trend is approximately parallel to the direction of the flight lines.

Among the products used for gamma ray spectrometric data interpretation were generated images of $\mathrm{K}(\%)$, eTh (ppm) and eU (ppm) and the ternary compositions RGB/KeTheU and $\mathrm{CMY} / \mathrm{KeTheU}$.

Trough the images for ternary composition with RGB and CMY was generated the map of compartmentation of gamma ray domains by visual classification. Ternary composition images were used because RGB and CMY best highlight, respectively, the high and low values.

The generated map of gamma ray spectrometric domains was used to evaluate the domains taking into account the geology, relief and pedogenetic (weathering/erosion) processes.

As the magnetometer readings refer to the Total Magnetic Field (TMF) values, with the contribution of both the, residual magnetism of the rocks and earth core, to generate the Anomalous Magnetic Field (AMF) data, representing the magnetic susceptibility of the rocks in the region, the International Geomagnetic Reference Field (IGRF) was removed using mathematical models. The removal of the IGRF resulted in the AMF, which represents the magnetic anomaly located on the crust above the Curie surface.

The magnetic data interpolation was performed by the bidirectional method (bi-grid, Geosoft, 2009), which resulted in greater detail of the magnetic anomalies in the study area.

The horizontal $X(D x)$ and $Y(D y)$ and the vertical $Z(D z)$ derivatives were generated from the Anomalous Magnetic Field (AMF), where the horizontal and vertical derivatives are used to enhance the horizontal gradients and thus the possible sources of the represented anomalies (high-pass filters) (Blum, 
1999). The vertical derivative from the filter $Z$ (Dz) amplifies the high frequency content rather than the low frequency acting as a high-pass filter.

Subsequently, the Analytical Signal Amplitude (ASA) was generated via Dx, Dy and Dz (Roest et al., 1992) derivatives using the following formula:

$$
\mathrm{ASA}=\sqrt{d x^{2}+d y^{2}+d z^{2}} .
$$

Analytical Signal Amplitude (ASA) allows the positioning of magnetic bodies because the technique comprises a symmetric function in which the analytical signal peaks are centered at the edges of the magnetic anomalies according to Nabighian (1972, 1974) and Roest et al. (1992).

From ASA product was applied unsupervised Mean-K classifications to generate the map of magnetic domains. This method first calculates the classes in a class uniformly distributed in space and agglomerates class by class in an iterative process, using the minimal distance technique (Tou \& Gonzalez, 1974).

Was generated the product Mafic Index (MI) that is a useful technique to individualize bodies of mafic and ultramafic origin (Pires \& Moraes, 2006) since this eliminates the influence of Fe-rich material present on the surface of the terrain (lateritic soil). The MI equation uses magnetic (ASA) and gamma spectrometric (K, eU and eTh) variables.

$$
\mathrm{IM}=\frac{\mathrm{ASA}}{(K \times U \times T h)} .
$$

\section{Relief}

The Digital Terrain Model (DTM) of the area was generated with data extracted from the Shuttle Radar Topography Mission (SRTM) project provided by the United States Geological Survey (USGS, 2000). The SRTM data display horizontal resolution (spatial resolution) of 3 arc-second $(\sim 90 \mathrm{~m})$ and vertical resolution of $1 \mathrm{~m}$, which allows mapping at scales between 1:100,000 and 1:250,000.

The SRTM data were converted to vector point type and interpolated using the Topo to Raster function (Hutchinson, 1988; 1989), in the ArcGIS 10, with pixel $30 \mathrm{~m} \times 30 \mathrm{~m}$ size. This procedure provides a better visual quality of DTM due to the change of spatial resolution to 30 meters, but keeping the information of the original 90-m resolution (SRTM). Relief information was generated using the DTM from which the maps of slope and hypsometry were derived. The slope and hypsometric maps were the main sources of information of relief features in the study area since their scales are more compatible with those of the geophysical maps. These maps were used to interpret the soil classes distribution and associated pedogenetic processes, due to the fact that the available map of soils is in a very small scale.

All procedures were performed in Geography Information System (GIS) environment, ArcGIS 10 software with its 3D Analyst and Spatial Analyst extensions (ESRI $\left.{ }^{\circledR}, 2011\right)$.

A 2.5 D image of the study area was generated using the DTM for better interpretation of $\mathrm{K}$, eU and eTh distribution regarding relief changes.

The generated maps of slope and hypsometric classes were the main sources of information regarding the relief features of the site since the scales were more compatible with those of the geophysical maps that is 1:100,000. The slope classes were also used to interpret soil distribution and pedogenic processes since the relief, particularly slope classes, along with geology, are the main factors determining the distinct soil classes formed while the soil map, available on a very small scale, was not consistent with the observations of soil types occurring in the area.

\section{RESULTS AND DISCUSSION Airborne Gammaspectrometry}

Gammaspectrometry is used to map changes on the concentration of potassium, uranium and thorium. The radiation emitted from the gamma ray reflects the chemical composition of the overlying rock and soil in relation to radionuclides (Wilford et al., 2001). Therefore, in eroded areas, the abundance of radioelements reflects the geochemistry and mineralogy of the rocks whereas in flattened areas the response is modified as a function of predominant pedogenesis processes.

The maps of K (\%) (Fig. 4), eTh (ppm) (Fig. 5) and eU (ppm) (Fig. 6) were used to interpret the Gamma spectrometry data, as well as the RGB and CMY combined ternary maps, for $\mathrm{K}$, eTh and $\mathrm{eU}$, respectively. To evaluate the correlation of gamma ray data with geology, topography and soil maps was used the Gamma spectrometry domain compartmentalization map, generated by the analysis of the RGB and CMY (Fig. 7) ternary maps.

The hypsometric and slope class maps show a quite varied relief with relationships with the geological and pedological units. In the Niquelândia Mafic-ultramafic Complex, N10E structural trends are evidenced in these maps by oriented ridges. These ridges are supported by the presence of chalcedony on top. The geomorphological flattened feature around the Mafic-ultramafic Complex is highlighted, except for some areas with slope class variations where quartzite rocks of the Serra da Mesa Group and pelitic-carbonate lithologies of the Paranoá Group occur (Figs. 8 and 9). 


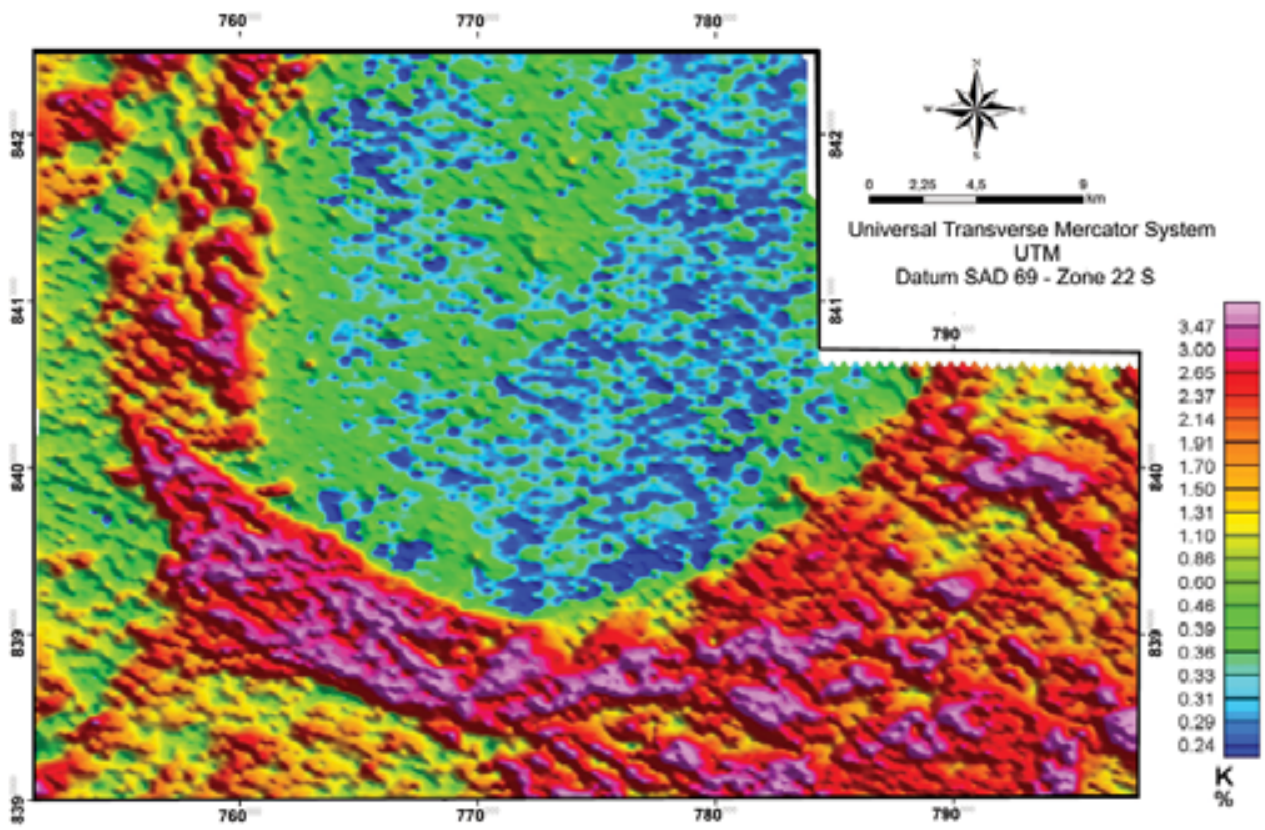

Figure 4 - Map of the potassium channel.

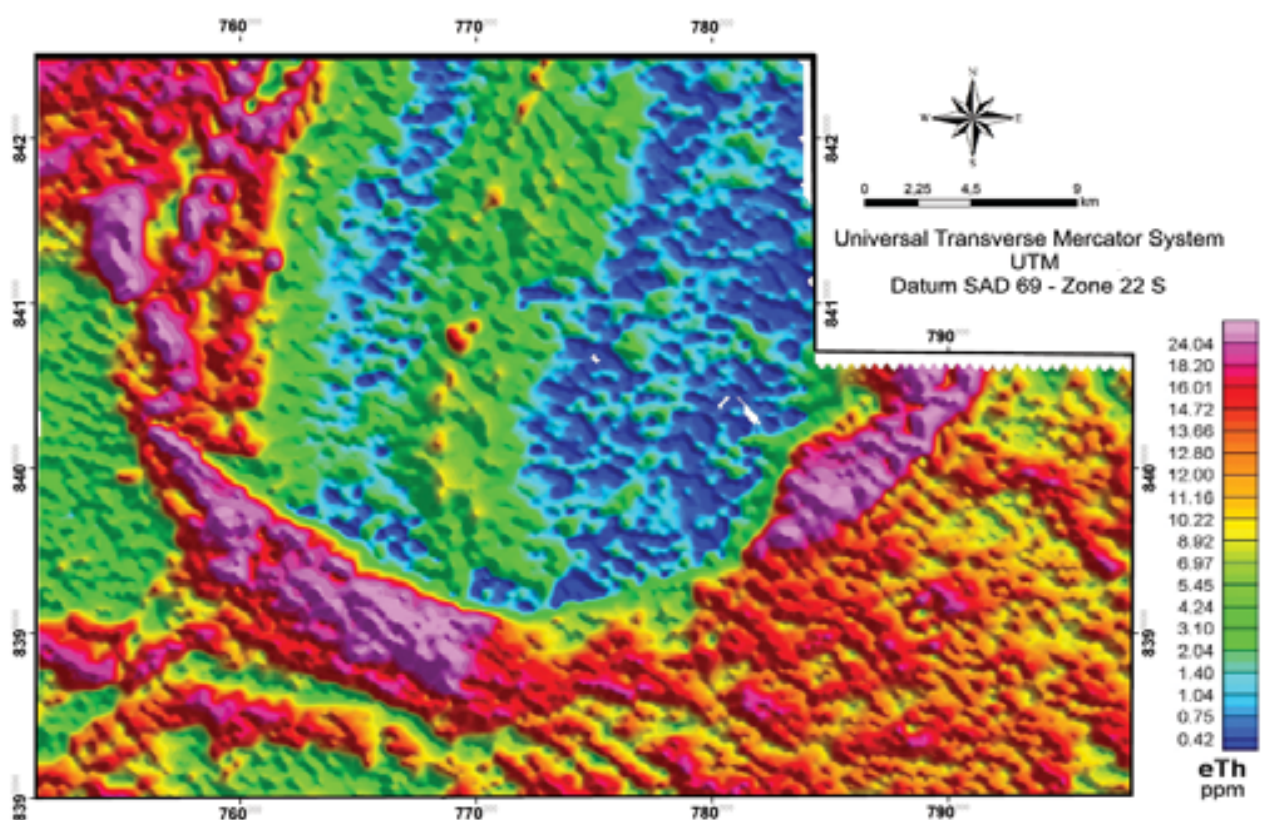

Figure 5 - Map of thorium channel.

Higher and steeper relief features were mapped in the eastern and western portions of the Niquelândia Mafic-Ultramafic Complex and in the quartzite unit of the Serra da Mesa Group (Figs. 8 and 9). Slope classes are more varied in the Paraná Group area (Fig. 9).

The $2.5 \mathrm{D}$ (Fig. 10) image of the study area highlights the N10E ridges and the pseudo-Dome feature of the Niquelândia
Complex, as described by Latrubesse \& Carvalho (2006). In the adjacent geological units it can be noted geomorphological variations, as described by Latrubesse \& Carvalho (2006), such as Regional Flattened Surfaces, Receding Erosion Zone, Mounts and Hills and Folded Structures forming Hogbacks, showing the influence of the on variation on airborne geophysical domains.

The map of distribution of gamma spectrometry domains 


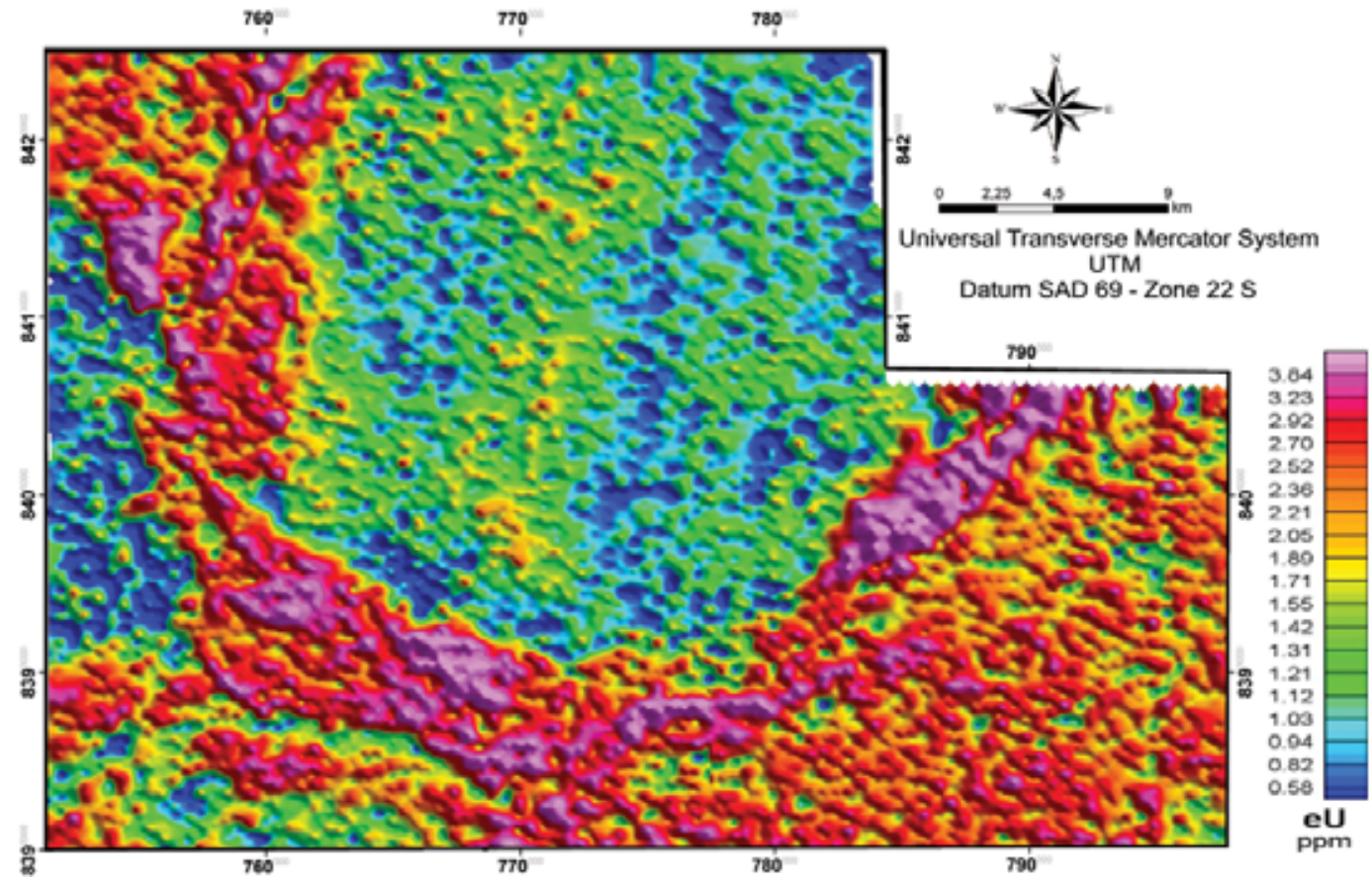

Figure 6 - Map of the uranium channel.

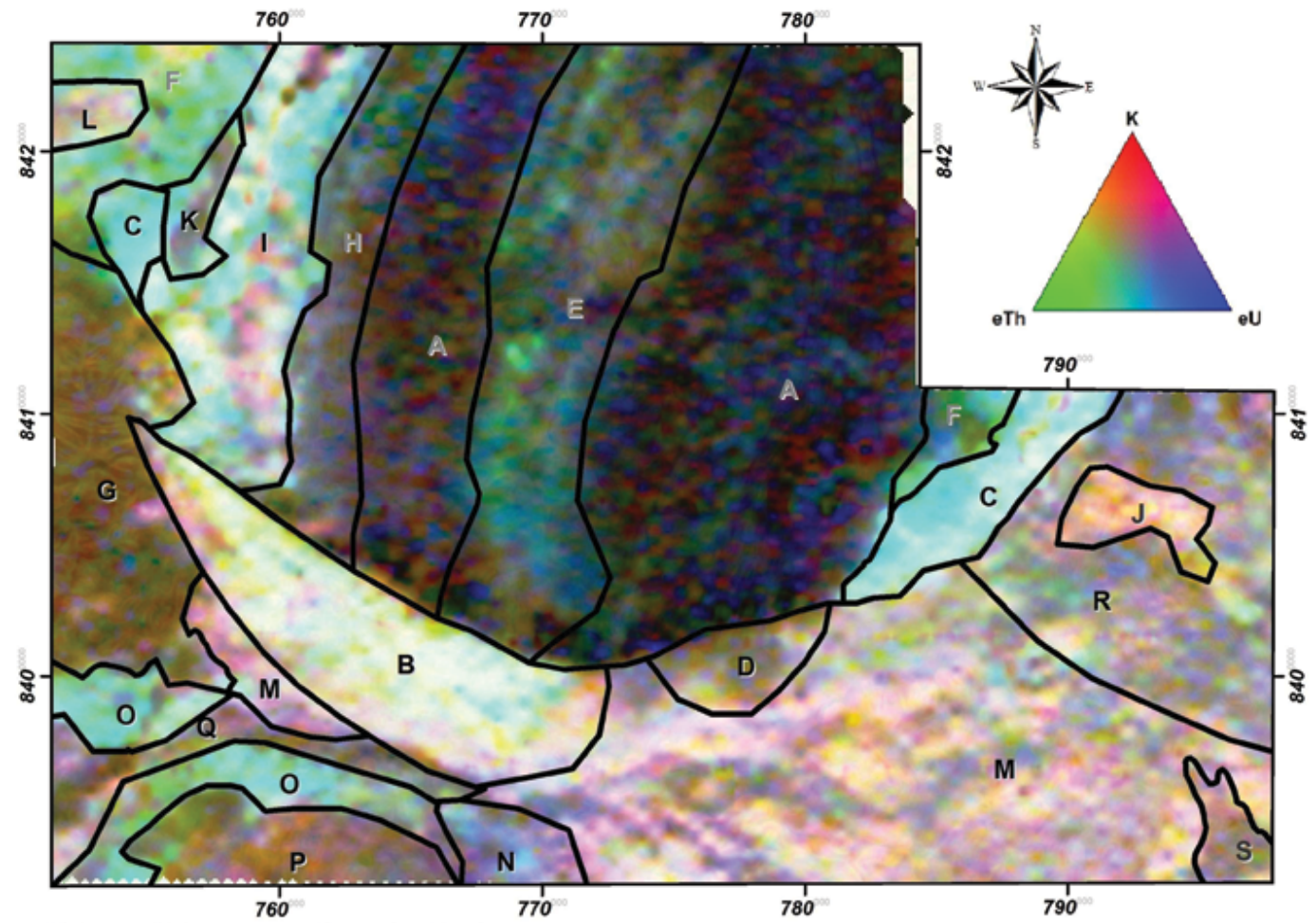

Universal Transverse Mercator System 。 UTM

Datum SAD 69 - Zone $22 \mathrm{~S}$

Figure 7 - Gamma ray spectrometric domains interpreted from the RGB and CMY ternary images and K (\%), eTh and eU (ppm) channels integrated with the digital terrain model from the SRTM. 


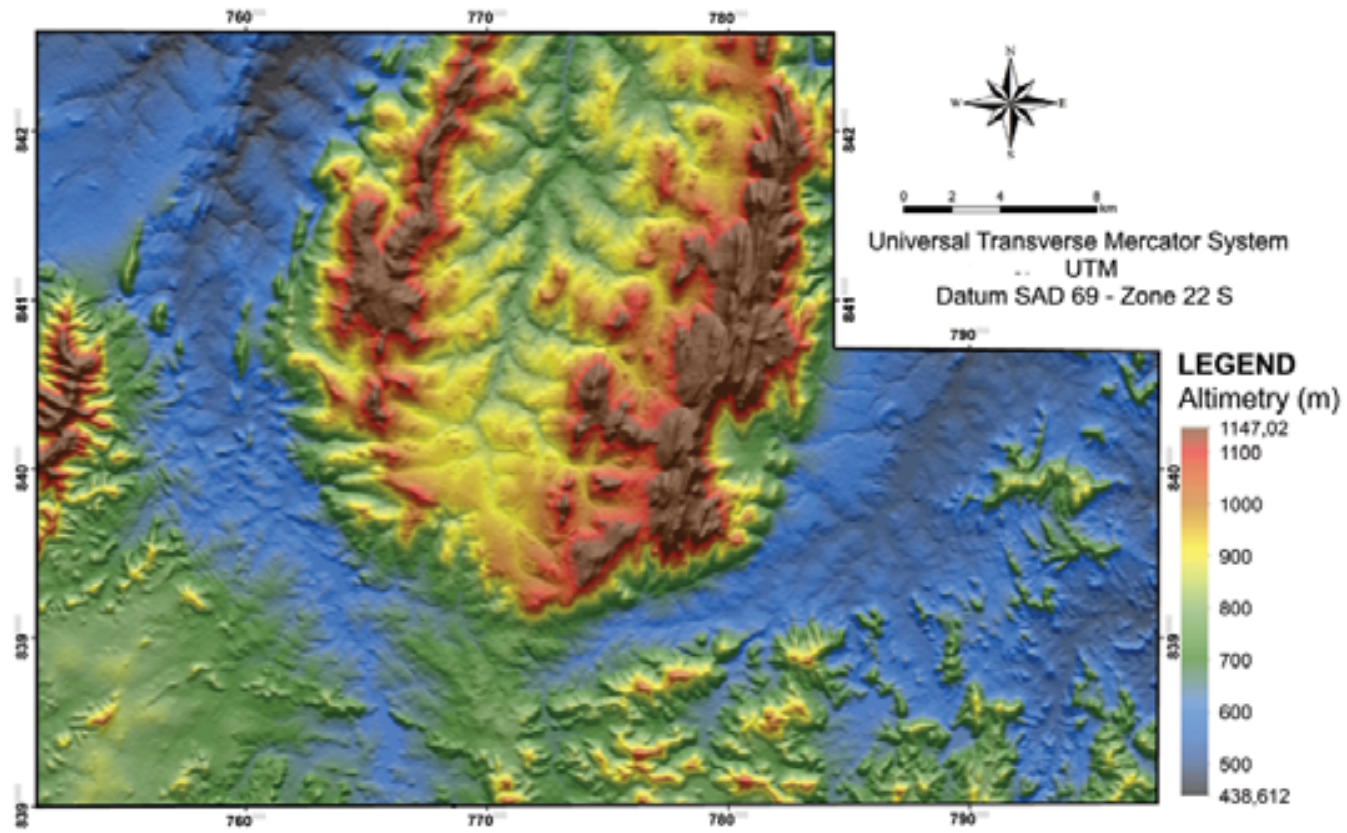

Figure 8 - Topographic map of the study area extracted from the DTM.

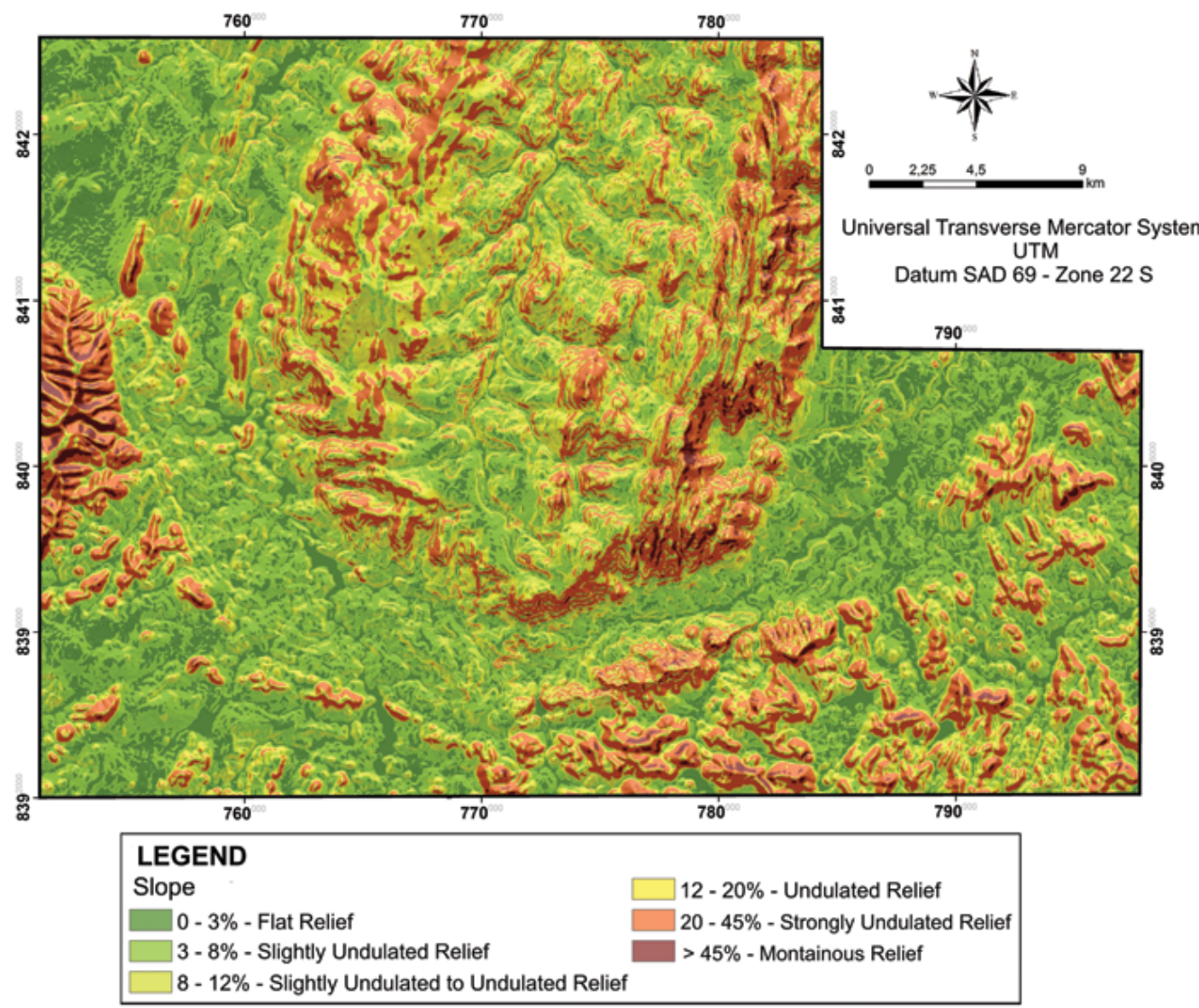

Figure 9 - Map of slope of the study area extracted from the DTM. 


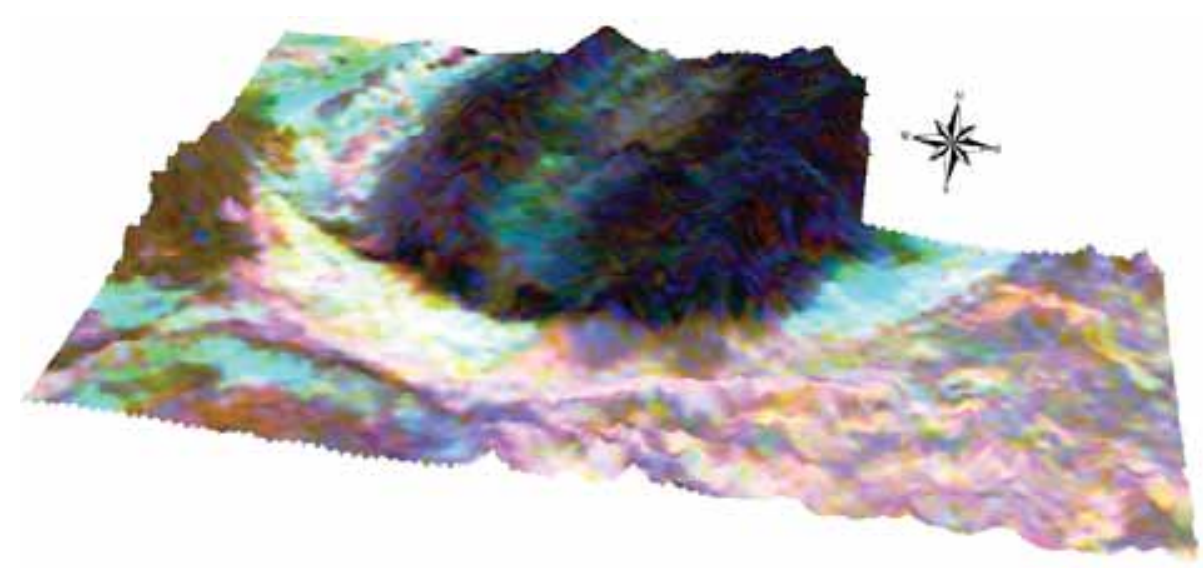

Figure 10 - Gamma spectrometry image associated with the $2.5 \mathrm{D}$ digital terrain model.

(Fig. 7) shows nineteen individualized domains named from A to $\mathrm{S}$. Their correlation with geology and slope is shown in Table 2 and are described as follows:

Domain $\mathbf{A}$ shows a good spatial correlation of the mapped area with the ferromagnesian rocks of the Niquelândia MaficUltramafic Complex, which are poor in the evaluated radionuclides. Low levels of radionuclides are typical of mafic and ultramafic rocks (Dickson \& Scott, 1997). The terrain is rugged, with the occurrence of preserved elongated ridges due to the presence of chalcedony on top of them, thus changing the pedogenic processes and soil classes. The presence of higher valleys formed on pyroxenite and marked by hills of dunites (Carvalho Júnior et al., 2004) can be observed in the Ultramafic Zone Complex. Due to the large geomorphological variation, soil classes can occur at very different evolution stages, such as Oxisoils, textutal B horizon soils, Inceptisoils and Entisoils. Mafic rocks exhibit low concentration of radionuclides due to its mineral chemistry (Carvalho, 2006). However, according to Dickson \& Scott (1997) these rocks have higher concentrations than those in dunites and peridodites.

Domain B, located in Rio Maranhão Complex, consists of granite-gneisses, which represent lithologies with high $\mathrm{K}$, eU and eTh concentration, arising from their geochemistry and mineralogy (Dickson \& Scott, 1997; Ulbrich et al., 2009). On the other hand, domain $\mathbf{D}$, which is located in the transition between Rio Maranhão Complex and Mafic Zone of the Niquelândia Complex, presents lower $\mathrm{K}, \mathrm{eU}$ and eTh concentration as a result of the composition of the basic rocks.

Domain C presents more pronounced pedogenic processes due to the lowest slope, forming Red Oxisoils rich in iron oxides and hydroxides, with eU and eTh associations, since these elements when released during weathering tend to be rapidly adsorbed on clay minerals and, due to geochemical affinity with $\mathrm{Fe}, \mathrm{co}$-precipitated with iron oxides and hydroxides in the soil (Wilford et al., 1997).

Domain $\mathbf{E}$ presents lower topography and more variation on eU and eTh concentrations. This may be due to a small slope variation and more active pedogenic processes in the source rock (gabbronorite), but can also be explained by its association with colluvial processes of soils with variable concentration on these elements. Potassium $(K)$, besides being depleted in the rock, is leached during the pedogenetic process, since this element has large mobility in the mineral changing process.

Domain $\mathbf{F}$ has high eU and eTh concentration associated to iron oxides and hydroxides (Wilford et al., 1997) in the schistose rocks of the Serra da Mesa Group and ferruginous lateritedetritic covering, the latter particularly in the eastern portion of the complex.

Domain $\mathbf{G}$ exhibits low concentration of radionuclides because its mineralogy is rich in silica due to the presence of quartzites of the Serra da Mesa Group in very rugged relief. These quartz-rich rocks can be identified by the low concentration of radionuclides, an association also used to map sandy soils (Wilford et al., 1997).

Domain $\mathbf{H}$ is located at the west end of the Niquelândia Complex associated to the lithologies of the Volcano-Sedimentary sequence of Indaianópolis, which is poor in $\mathrm{K}$. The relief with varying slope, where erosion processes predominate over pedogenesis, explains low eU and eTh concentrations.

Domain I shows high concentration of radionuclides, which are associated to the presence of gneisses and rhyolites from the Indaianópolis Volcano-Sedimentary Sequence. On the other hand, domain $\mathbf{L}$ shows spatial correlation with carbonate and mica-schists, which constitute the Unit B of Serra da Mesa Group. 
Table 2 - Characterization of Gamma spectrometry domains.

\begin{tabular}{|c|c|c|c|}
\hline Domain & Gamma spectrometry & Geology & Slope \\
\hline A & $\begin{array}{c}\text { Extremely low levels K, } \\
\text { eU and eTh }\end{array}$ & $\begin{array}{l}\text { Niquelândia Mafic- } \\
\text {-Ultramafic Complex }\end{array}$ & $\begin{array}{l}\text { Varies from flat } \\
\text { to strongly undulated }\end{array}$ \\
\hline B & $\begin{array}{c}\text { Extremely high levels } \mathrm{K}, \\
\mathrm{eU} \text { and eTh }\end{array}$ & $\begin{array}{l}\text { Rio Maranhão Complex } \\
\text { - granite-gneiss }\end{array}$ & $\begin{array}{l}\text { Varies from flat } \\
\text { to slightly undulated }\end{array}$ \\
\hline C & $\begin{array}{l}\text { High levels of eU } \\
\text { and eTh and low K }\end{array}$ & $\begin{array}{l}\text { Ferruginous lateritic-detritic cover } \\
\text { and Serra da Mesa Group-shale }\end{array}$ & Flat to slightly undulated \\
\hline $\mathrm{D}$ & $\begin{array}{l}\text { Moderate levels of eTh } \\
\text { and } \mathrm{K} \text { and low eU }\end{array}$ & $\begin{array}{l}\text { Rio Maranhão Complex } \\
\text { - granite-gneiss }\end{array}$ & Flat to undulated \\
\hline$E$ & $\begin{array}{l}\text { Moderate to high levels eTh } \\
\text { and eU and low to very low K }\end{array}$ & $\begin{array}{l}\text { Niquelândia Mafic-Ultramafic Complex } \\
\text { - Gabbronorite }\end{array}$ & $\begin{array}{l}\text { Flat to slightly undulated } \\
\text { Locally undulated to } \\
\text { strongly undulated }\end{array}$ \\
\hline $\bar{F}$ & $\begin{array}{l}\text { Showed high to very high for eTh, } \\
\text { moderate to high eU and high K }\end{array}$ & $\begin{array}{c}\text { Serra da Mesa Group-shale } \\
\text { and ferruginous lateritic-detritic cover }\end{array}$ & Flat to slightly undulated \\
\hline$G$ & $\begin{array}{l}\text { eTh low levels and } \\
\text { very low } \mathrm{K} \text { and eU }\end{array}$ & $\begin{array}{c}\text { Serra da Mesa Group } \\
\text { - Quartzite }\end{array}$ & $\begin{array}{l}\text { Strongly undulated } \\
\text { to mountainous }\end{array}$ \\
\hline $\bar{H}$ & $\begin{array}{l}\text { Low to moderate levels eTh } \\
\text { and } \mathrm{K} \text { and low to very low eU }\end{array}$ & $\begin{array}{l}\text { VSS-Indaianópolis Lower Unit } \\
\text { and Serra dos Borges Unit }\end{array}$ & $\begin{array}{c}\text { Undulated to } \\
\text { strongly undulated }\end{array}$ \\
\hline I & $\begin{array}{l}\text { Showed high } \mathrm{K} \text {, eU and } \\
\text { sometimes eTh channel } \mathrm{K} \\
\text { is higher than the other }\end{array}$ & $\begin{array}{l}\text { VSS Indaianópolis } \\
\text { - Lower and Upper Unit }\end{array}$ & Flat to slightly undulated \\
\hline $\mathrm{J}$ & $\begin{array}{l}\text { High levels of } \mathrm{K} \text { and } \\
\text { eTh and moderate eU }\end{array}$ & $\begin{array}{c}\text { Paranoá Group } \\
\text { - Rhythmic Pelite Carbonate }\end{array}$ & $\begin{array}{c}\text { Undulated to } \\
\text { strongly undulated }\end{array}$ \\
\hline $\mathrm{K}$ & $\begin{array}{l}\text { Very low levels and } \\
\text { eTh, } \mathrm{K} \text { and eU }\end{array}$ & $\begin{array}{l}\text { Ferruginous lateritic-detritic cover } \\
\text { and VSS Indaianópolis } \\
\text { - Upper Unit-Rhyolite and shale }\end{array}$ & Flat to undulated \\
\hline L & $\begin{array}{l}\text { Showed high to very high } \mathrm{K} \text {, } \\
\mathrm{eU} \text { and high for eTh }\end{array}$ & $\begin{array}{c}\text { Serra da Mesa Group-shale } \\
\text { and ferruginous lateritic-detritic cover }\end{array}$ & Flat to slightly undulated \\
\hline $\bar{M}$ & $\begin{array}{c}\text { Showed high to medium } \mathrm{K} \text {, } \\
\mathrm{eU} \text { and eTh }\end{array}$ & $\begin{array}{c}\text { Paranoá Group } \\
\text { - Rhythmic Pelite Carbonate }\end{array}$ & Flat to strongly undulated \\
\hline $\mathrm{N}$ & $\begin{array}{l}\text { High levels of eU and } \\
\text { eTh and average } K\end{array}$ & $\begin{array}{c}\text { Paranoá Group } \\
\text { - Rhythmic Pelite Carbonate }\end{array}$ & $\begin{array}{c}\text { Undulated to } \\
\text { strongly undulated }\end{array}$ \\
\hline 0 & $\begin{array}{l}\text { High levels for eTh and } \\
\text { moderate eU for } \mathrm{K}\end{array}$ & $\begin{array}{c}\text { Paranoá Group } \\
\text { - Rhythmic Pelite Carbonate }\end{array}$ & Flat to slightly undulated \\
\hline$P$ & $\begin{array}{l}\text { High levels of } \mathrm{K} \text { and moderate } \\
\text { to low eTh and low eU }\end{array}$ & $\begin{array}{c}\text { Paranoá Group } \\
\text { - Rhythmic Pelite Carbonate }\end{array}$ & $\begin{array}{l}\text { Flat to slightly undulated. } \\
\text { Occasionally undulated }\end{array}$ \\
\hline$Q$ & $\begin{array}{l}\text { High levels of } \mathrm{K} \text { and } \\
\mathrm{eU} \text { and moderate eTh }\end{array}$ & $\begin{array}{c}\text { Paranoá Group } \\
\text { - Rhythmic Pelite Carbonate }\end{array}$ & Flat to slightly undulated \\
\hline$R$ & $\begin{array}{c}\text { High levels of } \mathrm{K} \text { and } \\
\text { eTh and moderate to high eU }\end{array}$ & $\begin{array}{c}\text { Paranoá Group } \\
\text { - Rhythmic Pelite Carbonate }\end{array}$ & $\begin{array}{l}\text { Slightly undulated. } \\
\text { Strongly undulated, locally }\end{array}$ \\
\hline$S$ & $\begin{array}{l}\text { Moderate levels of } \mathrm{K} \text { and } \\
\text { eTh and low eU }\end{array}$ & $\begin{array}{c}\text { Paranoá Group } \\
\text { - Rhythmic Pelite-Carbonate Metalimestone }\end{array}$ & $\begin{array}{c}\text { Undulated to } \\
\text { strongly undulated }\end{array}$ \\
\hline
\end{tabular}

The domains $\mathbf{J}, \mathbf{M}, \mathbf{N}, \mathbf{O}, \mathbf{P}, \mathbf{Q}$ and $\mathbf{R}$ observed in the rocks of the Pelite-Carbonate Unit of the Paranoá Group, show variation on the concentration of $\mathrm{K}$, eU and eTh. This may be due to changing slope classes and relief, which cause forming processes of varied soils or more exposure of the rock.

Domain $\mathbf{S}$, located in the Pelite Carbonate-Metalime unit of the Paranoá Group presents undulated to strongly undulated relief, with larger influence of rocks compared to soils, which are slightly evolved.
The results from the interpretation of gamma spectrometric domains were based on $\mathrm{K}$, eU and eTh concentration, related to the series of factors that resulted from the geochemistry of rocks, relief type and activity degree of pedogenic processes.

In the weathering processes, the radioelement $\mathrm{K}$ is geochemically mobile and leaches in the first stages of mineralogical alteration. It is present in feldspar, mica, and clay minerals such as illite and montmorillonite and, in lower proportions, in kaolinite (Wilford et al., 1997), and thus, tends to concentrate in young 
soils derived from felsic rocks, such as those constituting the Rio Maranhão Complex as well as in gneisses and rhyolites of the Indaianópolis Volcano-Sedimentary Sequence. According to Dickson \& Scott (1997), potassium is virtually absent in mafic minerals, so in areas of mafic and ultramafic rocks the radiometric levels of this element are low.

On the contrary, eU and eTh are less mobile than $\mathrm{K}$ in alteration and pedogenesis processes. However, the level of these elements in soils are dependent on their source material, i.e., concentrations are higher when soils derive from granitic rocks, alkaline igneous rocks, schists and gneisses; and lower, when soils are formed from basic igneous rocks and carbonate rocks. Uranium and thorium when released during weathering are adsorbed on clay minerals or co-precipitated with iron oxides and hydroxides in the soil (Wilford et al., 1997), the latter being concentrated in more evolved soils, developed on relief with slope changing from flat to slightly undulated. This behavior has been observed in the study area, especially where the cover is detriticlaterite ferruginous.

Pedogenesis plays an important role on the identification and distribution of radionuclides on the surface since soil uranium and thorium content is highly variable. Therefore, a given gamma spectrometric analysis must take into account the whole physical context of the study area; not only the geology, but also the relief and all pedogenic processes that are active on soil formation.

\section{Airborne Magnetometry}

Magnetic information was used to differentiate the litho-types based on the magnetic susceptibility and possible magnetic features noted on the surface. The analysis of airborne magnetic data through ASA process resulted the identification and classification of five magnetic domains (very high, high, moderate, low and very low intensity). This process contributed for a better discrimination of the magnetic signature (Milligan \& Gunn, 1997) of the Niquelândia Complex lithology and adjacent geological units, based on the Analytical Signal Amplitude - ASA. (Figs. 11 and 12).

In a general context, the magnetic domains (Fig. 12) whose magnetic field intensity ranged from moderate to very low are associated to the sedimentary rocks of Paranoá and Serra da Mesa Groups. High to very high magnetic values occur in some portions of the Niquelândia Mafic-Ultramafic Complex, especially in the Ultramafic Zone and Indaianópolis Volcano-Sedimentary sequence, results achieved by Blum (1999) for the same region and by Carrino et al. (2007), in the Carajás Mineral Province for mafic/ultramafic rocks. Magnetic highs were also observed in the eastern portion of the studied area, which may have been influenced by iron oxides and hydroxides rich soils. In the eastern portion of the complex an anomalous feature with magnetic high is associated with Votorantims nickel plant.

\section{Mafic Index}

After the analysis of the airborne gamma spectrometric and magnetic data, the Mafic Index (MI) was calculated combining both, magnetic and gamma spectrometry data (Fig. 13). This product allows removal of the influence of iron-rich soils and thus enhancing the magnetic signatures caused by the source lithology. The Ml product of the Complex area allowed distinguishing the magnetic features generated by the source rocks from that produced by the soils (Fig. 13).

Individualized portions with high Mafic Index (MI), as seen in Figure 13, correspond to features with higher magnetic field intensity (magenta and red) associated to the presence of mafic and ultramafic rocks, which comprise the Lower and Upper Magmatic Sequences of the Niquelândia Mafic-Ultramafic Complex, most notably the Ultramafic Zone (Fig. 2). The lower MI areas represent adjacent units (green and yellow) of the Complex corresponding to the rocks of Rio Maranhão Complex, the metavolcano-sedimentary sequence of Indaianópolis and metasedimentary rocks of the Paranoá and Serra da Mesa Groups (Fig. 2). The areas with high magnetic intensity observed in the ASA map were discarded in the $\mathrm{Ml}$, because this is probably caused by shallow sources such as the iron-rich soils.

\section{Profiles of the Integration of Geophysical, Lithological and Relief Data}

The profile stacking geophysical and hypsometric data associated with geology allowed an integrated view and was useful to interpret their relationship. The profiles were generated along an airborne geophysical control line, with WE direction, transverse to the trend of the Niquelândia Complex lithologies, located in the central portion of the study area. The location of the lines where the profiles have been generated is found in the Analytical Signal Amplitude map (Fig. 11). Profiles with $\mathrm{K}$, eU and eTh concentration and Anomalous Magnetic Field (AMF) are displayed together with the lithological units and hypsometric data (Fig. 14).

The evaluation of the profiles shows the influence of lithology and topography on the airborne geophysical data, represented by the hypsometry. The Serra da Mesa Group with quartz composition shows values ranging from low to very low for radionuclides and for the AMF, with strongly undulated relief. The Rio Maranhão Complex has high $\mathrm{K}$, moderate eTh and eU con- 


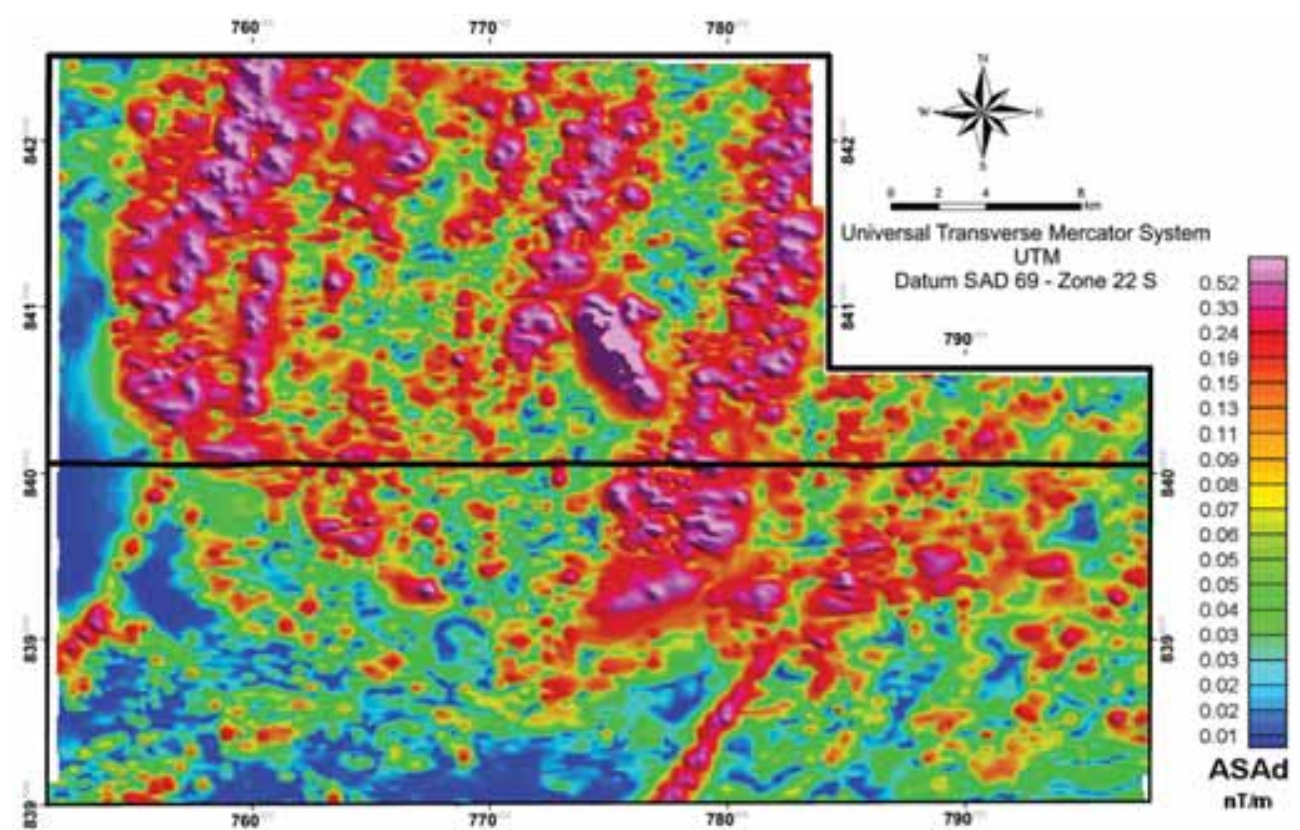

Figure 11 - Map of the Analytical Signal Amplitude.

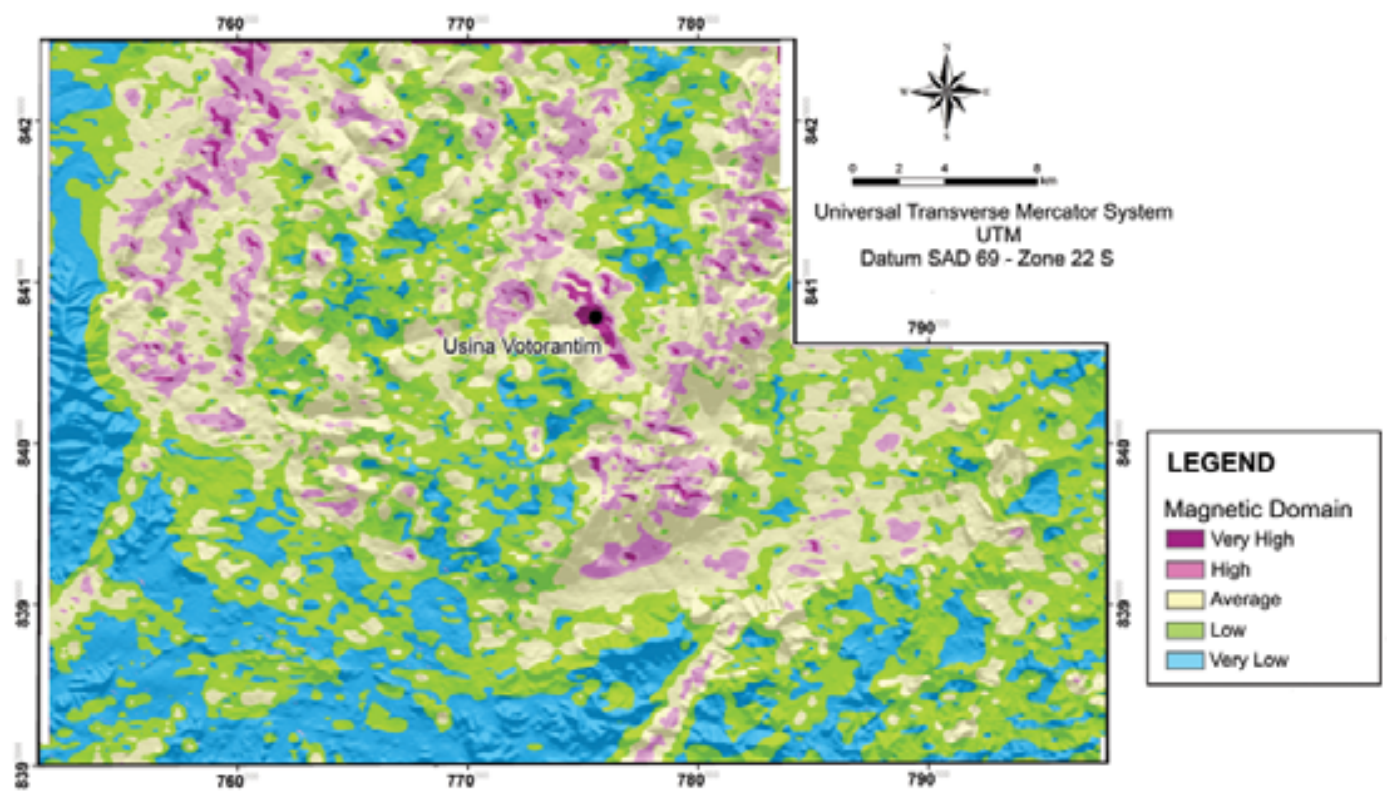

Figure 12 - Magnetic fields generated from the ASA product.

centrations and the relief is flatter. The Indaianópolis VolcanoSedimentary Sequence has high $\mathrm{K}$ and eTh, low eU, and flatter relief. The intensity values of the magnetic field were between moderate and low for these two lithological units. In the Niquelândia Mafic-Ultramafic Complex, $\mathrm{K}$, eU and eTh concentrations were very low; however, a slight increase in the concentrations of eTh was observed. The highest magnetic intensities occurred in the
Superior Mafic and Ultramafic units, where the relief becomes quite varied. The ferruginous lateritic-detritic covering showed high eTh and eU, and low K concentrations; moderate to high magnetic field intensity and flatter relief. The Paranoá Group has high $\mathrm{K}$, moderate eTh and from moderate to low eU. The magnetic field intensity varied from moderate to very low on a varying slope relief. 


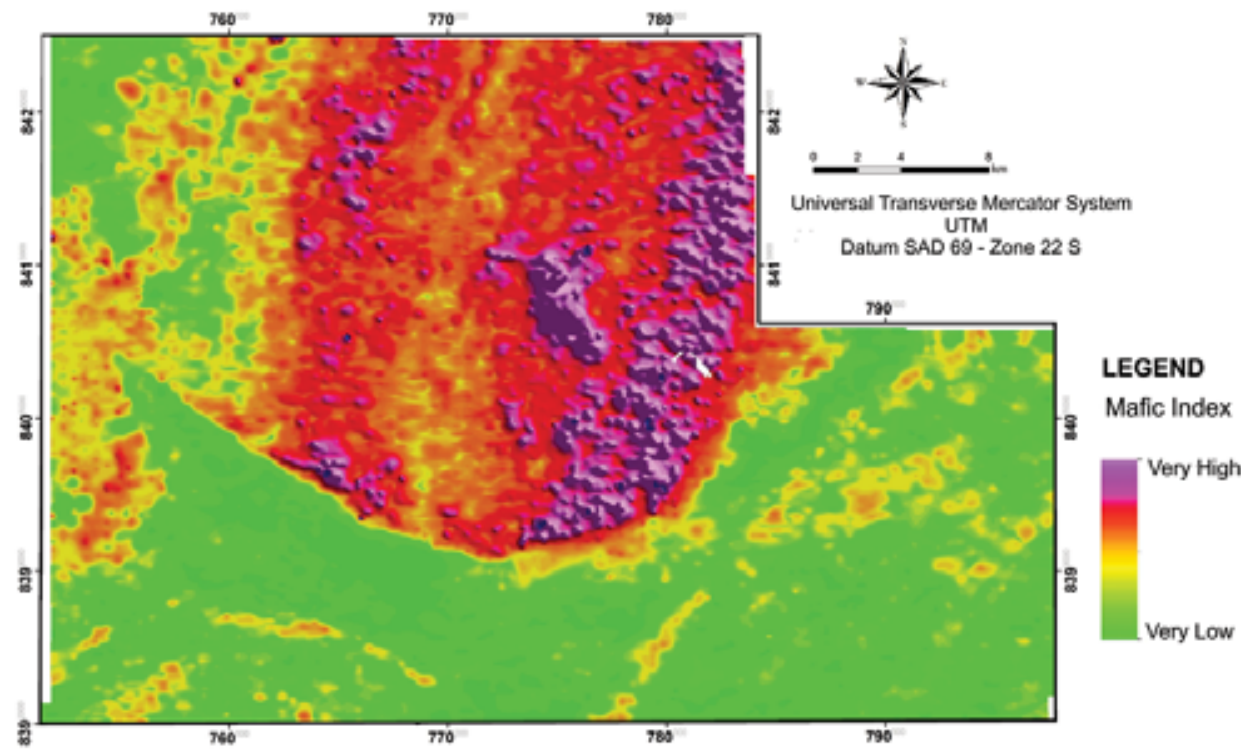

Figure 13 - Map of Mafic Index

\section{$\stackrel{x}{n}$}

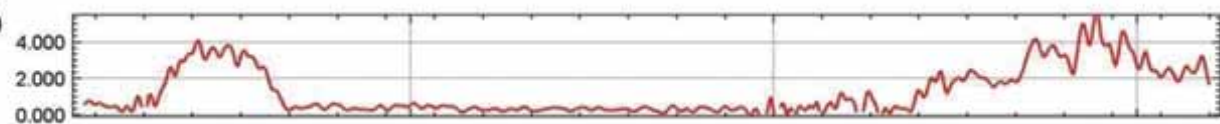

en

(1)

8.000

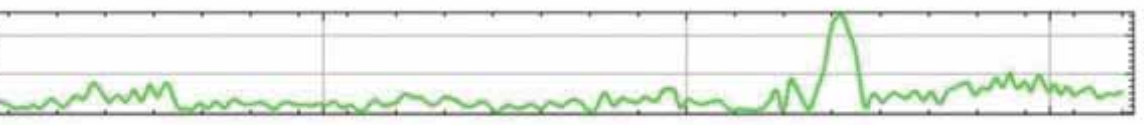

in

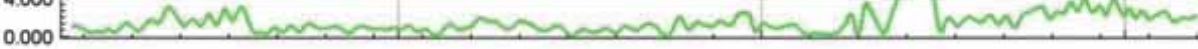

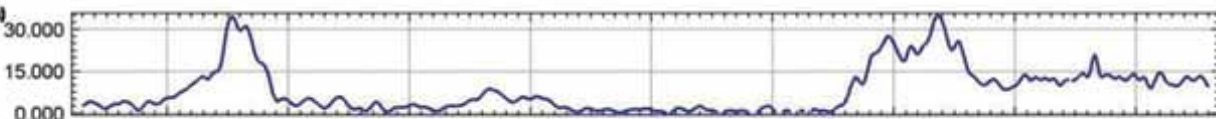

one
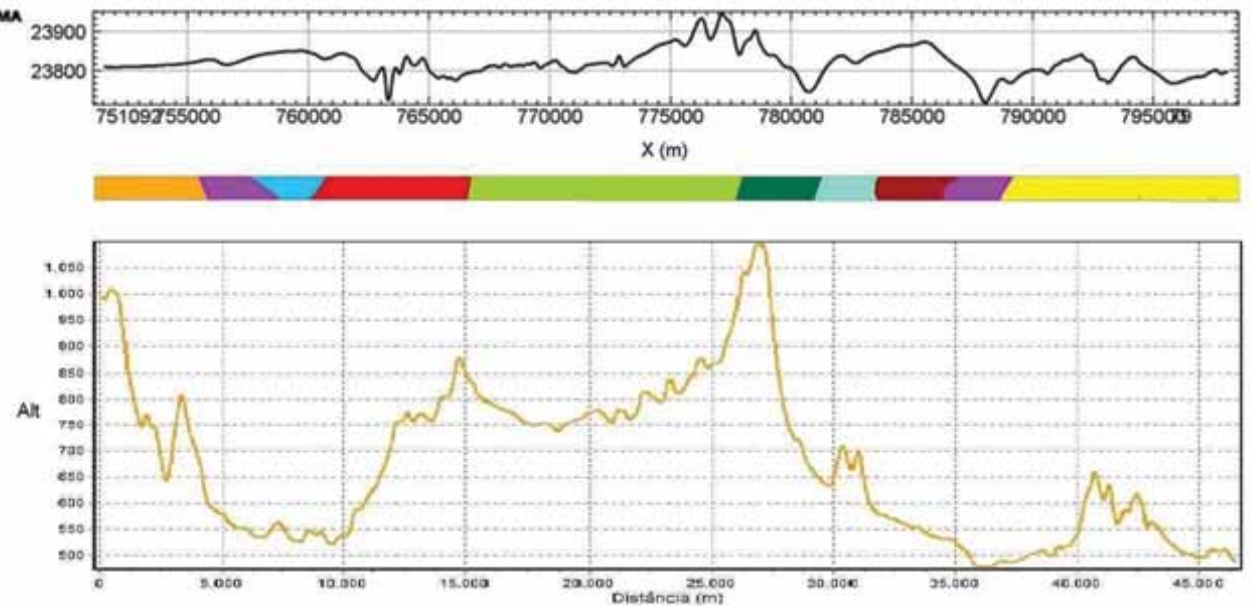

Profile Lithologies

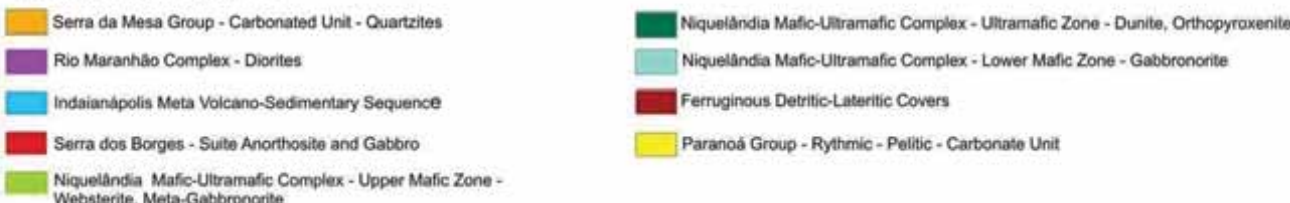

Figure 14 - Profiles of the control line of K, eTh, AMF, lithology and relief (W-E direction). 


\section{CONCLUSIONS}

The map of gamma spectrometry domains allowed to evaluate changes in the $\mathrm{K}, \mathrm{eU}$ and eTh concentration, enabling to differentiate the geological units of the Niquelândia Mafic-ultramafic Complex; the lithology of the Indaianápolis Volcano-sedimentary Sequence; and, the predominantly granite-gneissic and sedimentary lithologies of the Rio Maranhão Complex, Paranoá and Serra da Mesa Groups. These geological units presented varied levels of $\mathrm{K}$, eU and eTh as a function of their correlation with the geology, topography and soil classes, which led to the individualization of nineteen gamma spectrometric domains.

The gamma spectrometric domains compounded by mafic and ultramafic rocks of the Niquelândia Complex occur predominantly in areas of rugged relief and forming of slightly evolved soil with low values of $\mathrm{K}$, eU and eTh, showing gamma spectrometry response clearly opposed to felsic rock domains, which are rich in radionuclides, of the Rio Maranhão Complex, Paranoá and Serra da Mesa Groups. In areas of smooth terrain, varying from flat to gently undulate with slopes that characterize the relief of Niquelândia Complex. These characteristics are in favor of forming more evolved soils, where is observed loss of $\mathrm{K}$ and eU and eTh, due to $\mathrm{K}$ leaching and concentration of eU and $\mathrm{eTh}$, associated with iron oxides and hydroxides through the pedogenic processes.

Gamma spectrometric domains with predominantly pedological coverage had higher levels of e $\mathrm{U}$ and $\mathrm{eTh}$ and lower $\mathrm{K}$, due to high mobility of the latter and co-precipitation of eU and eTh with $\mathrm{Fe}$ and $\mathrm{Al}$ oxides and hydroxides in pedogenenic environment.

Interpreted through the Analytical Signal Amplitude the magnetic data were separated into five magnetic domains, associated to the lithological variability of the studied region. The zones consisting of mafic-ultramafic rocks were highlighted and had high magnetic values, depending on the predominant ferromagnesian minerals in their lithologies, especially in units of the Niquelândia Complex and Indaianápolis Volcano-Sedimentary Sequence. On the other hand the zones with predominant granite-gneiss and sedimentary rocks of Rio Maranhão Complex, Paranoá and Serra da Mesa Groups had low magnetic values, consistent with the iron-depleted lithologies of these geological units.

The processing of the gamma ray spectrometric and magnetic data using the Mafic Index allowed individualizing the Niquelândia Mafic-Ultramafic Complex from its adjacent geological units, highlighting, in addition, the ultramafic rocks site. This result proves the efficiency of the Mafic Index (MI) to differentiate the mafic-ultramafic rocks since it eliminates the surface magnetic response, that result from altered rocks and soils and emphasizes the magnetic response of the underlying rock.
The analyses of the correlation of the airborne geophysical magnetic and gamma spectrometric data related to the geochemical composition of rocks, topographic features, soil classes and pedogenic processes, allowed to interpret the variation of geophysical data as well as to individualize the Niquelândia MaficUltramafic Complex from its adjacent geological units.

\section{REFERENCES}

ALMEIDA L, RESENDE L, RODRIGUES AP \& CAMPOS JEG. 2006. Hidrogeologia do Estado de Goiás. Secretaria de Indústria e Comércio. Superintendência de Geologia e Mineração. Goiânia, 232 pp.

BLUM MLB. 1999. Processamento e interpretação de dados de geofísica aérea no Brasil Central e sua aplicação à Geologia Regional e à Prospecção Mineral. Doctorade Thesis on Geology - Universidade de Brasília. Brasília. 229 pp.

BRITO NEVES BB, VAN SCHMUS WR, SANTOS EJ, CAMPOS NETO MC \& KOZUCH M. 1995. 0 evento Cariris Velhos na Província Borborema: integração de dados, implicações e perspectivas. Revista Brasileira Geociências, 25: 279-296.

CARRINO TA, SOUZA FILHO CR \& LEITE EP. 2007. Avaliação do uso de dados aerogeofísicos para mapeamento geológico e prospecção mineral em terrenos intemperizados: o exemplo de Serra Leste, província mineral de Carajás. Revista Brasileira Geofísica, 25(3): 307-320.

CARVALHO LMM. 2006. Integracão de dados de geofísica aérea aplicada a geologia e a prospeccão mineral no Distrito Esmeraldífero de Itabira-Ferros, Quadrilátero Ferrífero, MG. Doctorade Thesis on Geology - Universidade de Brasília, Brasília. 178 pp.

CARVALHO JÚNIOR OA, MARTINS ES, CARVALHO APF, MENESES PR, GUIMARÃES RF \& CARDOSO FBF. 2004. Estimativa da abundância de minerais do depósito de níquel laterítico da mina Fazenda por espectrorradiometria. Revista Brasileira Geociências, 34(4): 579-586.

CORREIA CT, GIRARDI VAV, LAMBERT DD, KINNY PD \& REEVES SJ. 1996. 2 Ga U-Pb (SHRIMP-II) and Re-Os ages for the Niquelândia Basic-Ultrabasic Layered Intrusion, Central Goiás, Brazil. In: Congr. Bras. Geol., 39. 1996. Salvador. Proceedings... Salvador: SBG, 1996. p. $187-189$

CORREIA CT, GIRARDI VAV, TASSINARI CCG \& JOST H. 1997. Rb-Sr and Sm-Nd Geocronology of the Cana Brava layered mafic-ultramafic intrusion, Brazil, and considerations regarding its tectonic evolution. Revista Brasileira Geociências, 27: 163-168.

CORREIA CT, JOST H, TASSINARI CCG, GIRARDI VAV \& KINNY PD. 1999. Ectasian Mesoproterozoic U-Pb Ages (Shrimp II) for the meta Volcanosedimentary sequences of Juscelândia and Indaianópolis and for high grade metamorphosed rocks of Barro Alto stratiform igneous Complex, Goiás State, Central Brazil. In: S. Amer. Symp. Isot. Geol., 2: 1999, Córdoba. Actas... Córdoba: 1999. p. 31-33. 
DANNI JCM \& LEONARDOS OH. 1978. As Sequências granulítica, anortosítica-anfibolítica e ultramáfica da região de Niquelândia-G0. In: Congr. Bras. Geol., 30.: 1978, Recife. Abstracts... Recife: SBG, 1978. p. 45.

DANNI JCM \& LEONARDOS OH. 1980. Granulite metamorphism and deformation in ancient composite layered intrusions: the Niquelândia Complex, Brazil. Inter. Geol. Congr., 26.: 1980, Paris. Abstracts... Paris, 1980. p. 35.

DANNI JCM, FUCK RA \& LEONARDOS OH. 1982. Archean and lower Proterozoic Units in Central Brazil. Geologische Rundschau. 71: 291317.

DARDENNE MA. 1978. Zonação tectôncia da borda ocidental do cráton do São Francisco. In: Congr. Bras. Geol., 30.: 1978, Recife. Anais... Recife: SBG, 1978. p. 299-308.

DARDENNE MA. 2000. The Brasília fold belt. In: CORDANI UG, MILANI EJ, THOMAZ FILHO A \& CAMPOS DA (Ed.). Tectonic evolution of South America. Rio de Janeiro, DNPM, p. 231-263.

DARDENNE MA \& FARIA A. 1985. Estratigrafia do Grupo Paranoá na região de Alto Paraíso - G0. In: Simp. Geol. Centro-Oeste, 2.: 1985, Goiânia. Anais ... Goiânia: SBG. 1985. p. 65-71.

DICKSON BL \& SCOTT KM. 1997. Interpretation of aerial gamma-ray surveys - adding the geochemical factors. AGSO Journal Australian Geology and Geophysics, 17: 187-200.

EDDY BG, BONHAM-CARTER GF \& JEFFERSON CW. 2010. Mineral potential analyzed and mapped at multiple scales - a modified fuzzy logic method using digital geology. In: HARRIS JR (Ed.). GIS Applications in Earth Sciences: Special Publication. Geological Association of Canada, Special Publication, 44: 143-162.

ESRI. 2011. ArcGIS, Spatial Analyst, 3D Analyst Versão 10. Environmental Systems Research Institute.

FARIA A \& DARDENNE MA. 1995. Estratigrafia do Grupo Paranoá na região Alto Paraiso de Goiás - São João da Aliança. In: Simp. Geol. Centro-Oeste, 5.: 1995, Goiânia. Anais... Goiânia: SBG, 1995. p. 7576 .

FERREIRA FILHO CF \& NALDRETT AJ. 1993. The Niquelândia maficultramafic complex revisited: tectonic setting and potential for PGE deposits. In: Brazilian PGE Meeting, 1.: 1993, Brasília. Abstract... Brasília: SBG, 1993. p. 25-28.

FERREIRA FILHO CF \& PIMENTEL MM. 1999. Sm-Nd Isotop Sistematic and Ree-Hf-Ta-Th data for mafic rocks of the Niquelândia Complex upper layered series, Central Brazil: further constraints for the timing of magmatism and high grade metamorphism. In: S. Amer. Symp. Isot. Geol. 2.: 1999, Cordoba. Actas... Córdoba: 1999. p. 60-62.

FERREIRA FILHO CF, NILSON AA \& NALDRETT AJ. 1992. The Niquelândia Mafic-Ultramafic Complex, Goias, Brazil: a contribution to the ophiolite $X$ stratiform controversy based on new geological and structural data. Precambrian Research, 59: 125-143.

FERREIRA FILHO CF, KAMO S, FUCK RA, KROGH TE \& NALDRETT AJ. 1994. Zircon and rutile geochronology of the Niquelândia layered mafic ana ultramafic intrusion, Brazil: constraints for the timing of magmatism and high grade metamorphism. Precambrian Research, 68: 241-255.

FERREIRA FILHO CF, MORAES RD, FAWCETT JJ \& NALDRETT AJ. 1998. Amphibolite to Granulite Progressive Metamorfism in The Niquelândia Complex, Central Brazil: Regional Tectonic Implication. Journal South American Earth Sciences, 11(1): 35-50.

FUCK RA. 1994. A Faixa Brasília e a compartimentação tectônica na Província Tocantins. In: Simpósio Geologia Centro-Oeste, 4, Brasília, DF. 1994. Anais... Brasília, SBG, p. 184-187.

FUCK RA, MARINI OJ, DARDENNE MA \& FIGUEIREDO AN. 1988. C0berturas metassedimentares do Proterozóico Médio: os Grupos Araí e Paranoá na região de Colinas, Goiás. Revista Brasileira Geociências, 18: 56-62.

FUCK RA, DANTAS EL, PIMENTEL MM, LAUX JH, JUNGES S, OLIVEIRA CG, DE SORDI DA \& CHIARINI MFN. 2006. Sequência Santa Terezinha de Goiás, Brasil: novos dados geológicos, Idades U-Pb em zircão e dados isotópicos. In: Congr. Bras. Geol., 43.: 2006, Aracaju. Anais... Aracaju: SBG, 2006. p. 129-129.

GEOSOFT. 2009. Oasis Montaj 7.1. Geosoft, Inc., Toronto.

GIRARDI VAV, RIVALENTI G \& SINIGOI S. 1986. The petrogenesis of the Niquelândia layered basic-ultrabasic complex, Central Goiás, Brazil. Journal Petrology, 27: 715-744.

G00GLE EARTH. 2013. Available on: <http://www.google.com.br/earth/index.html>. Access on: Jan. 15, 2013.

HASUI Y \& ALMEIDA FFM. 1970. Geocronologia do Centro-Oeste Brasileiro. Bol. Soc. Bras. Geol., 19: 7-26.

HUTCHINSON MF. 1988. Calculation of hydrologically sound digital elevation models. In: Third International Symposium on Spatial Data Handling at Sydney, Australia. International Geographical Union, Columbus, Ohio, 13-33.

HUTCHINSON MF. 1989. A new procedure for gridding elevation and stream line data with automatic removal of spurious pits. Journal Hydrology, 106: 211-232.

LASA ENGENHARIA E PROSPECÇÕES S.A. 2006. Levantamento Aerogeofísico do Estado de Goiás - Paleo-Neoproterozóico do Nordeste de Goiás - Convênio SGM/ MME/ CPRM-SIC/ SGM/ FUNMINERAL. Relatório Final do Levantamento e Processamento dos Dados Magnetométricos e Gamaespectrométricos, Volume I - Texto Técnico.

LATRUBESSE EM \& CARVALHO TM. 2006. Geomorfologia do Estado de Goiás e Distrito Federal. Superintendência de Geologia e Mineração do Estado de Goiás, Goiânia, Brasil, 143 pp. 
MAMEDE L, NASCIMENTO MALS \& FRANCO MS. 1981. Geomorfologia. In: Projeto RadamBrasil. Folha SD.22 Goiás. Rio de Janeiro. (Levantamento de Recursos Naturais, 25)

MANTOVANI MSM \& BRITO NEVES BB. 2005. The Paranapanema lithospheric block: its importance for Proterozoic (Rodinia, Gondwana) supercontinent theories. Gondwana Research, 8: 303-315.

MARINI OJ, FUCK RA, DARDENNE MA \& FARIA A. 1977. Contribuição à geologia do Pré-Cambriano da porção central de Goiás. Revista Brasileira Geociências, 7: 304-324.

MARINI OJ, FUCK RA, DANNI JCM, DARDENNE MA, LOGUEIRO SOC \& RAMALHO R. 1984. As faixas de dobramentos Brasília, Uruaçu e Paraguai-Araguaia e o Maciço Mediano de Goiás. In: SCHOBBENHAUS C, CAMPOS DA, DERZE GR, ASMUS HE (Coords.). Geologia do Brasil. DNPM. Brasília. 251-303p.

MEDEIROS ES \& FERREIRA FILHO CF. 2001. Caracterização geológica e estratigráfica das mineralizações de Platina e Paládio associadas à Zona Máfica Superior do Complexo de Niquelândia, GO. Revista Brasileira Geociências, 31(1): 29-36.

MILLIGAN PR \& GUNN PJ. 1997. Enhancement and presentation of airborne geophysical data. AGSO Journal Australian Geology and Geophysics, 17: 63-75.

MOREIRA MLO, MORETON LC, ARAÚJO VA, LACERDA FILHO JV \& COSTA HF. 2008. Geologia do Estado de Goiás e Distrito Federal. Escala 1:500.000. Goiânia: CPRM/SIC-FUNMINERAL.

MOTTA J, LINDENMAYERD \& SILVEIRA NC. 1970. Geologia do Maciço São José do Tocantins. In: Congr. Bras. Geol., 24; Roteiro Excursão, Bol. Esp. p. 32-37.

MOTTA J, ARAÚJO V, MELLO JCR \& OGUINO K. 1972. Projeto Niquelândia. Relatório Final. Goiânia, DNPM/CPRM. v. 1, 224 p.

NABIGHIAN MN. 1972. The analytic signal of two-dimensional magnetic bodies with polygonal cross-section: Its properties and use for automated anomaly interpretation. Geophysics, 37: 507-517.

NABIGHIAN MN. 1974. Additional comments on the analytic signal of two-dimensional magnetic bodies with polygonal cross-section. Geophysics, 39: 85-92.

NASCIMENTO MALS. 1991. Geomorfologia do Estado de Goiás. Boletim Goiano de Geografia. Goiânia: UFG, v. 12, n. 1

NASCIMENTO FS, VELOSO FDLM \& SABÓIA LA. 1981. Caracterização e discussão sobre a Seqüência Volcano-Sedimentar da Borda Oeste do Maciço de Niquelândia (W do Rio Traíras). In: Simp. Geol. Centro-Oeste, 1.: 1981, Goiânia. Atas... Goiânia: SBG, 1981. p. 470-492.

NYKÄNEN V, GROVES DI, OJALA VJ, EILU P \& GARDOLL SJ. 2008. Reconnaissance-scale conceptual fuzzy-logic prospectivity modelling for iron oxide copper - Gold deposits in the northern Fennoscandian shield, Finland. Australian Journal of Earth Sciences, 55: 25-38.

PECORA WT \& BARBOSA ALM. 1944. Jazidas de níquel e de cobalto de São José de Tocantins, estado de Goiás. DNPM/DFPM, Boletim 64 p.

PIMENTEL MM \& FUCK RA. 1992. Neoproterozoic crustal accretion in central Brazil. Geology, 20: 375-379.

PIMENTEL MM, HEAMAN L, FUCK RA \& MARINI OJ. 1991. U-Pb zircon geochronology of Precambrian tin-bearing continental-type acid magmatism in central Brazil. Precambrian Research, 52: 321-335.

PIMENTEL MM, FUCK RA \& FISCHEL DP. 1999. Estudo isotópico Sm$\mathrm{Nd}$ regional da porção central da Faixa Brasília: implicações para idade e origem dos granulitos do Complexo Anápolis-Itauçu e sedimentos do Grupo Araxá. Revista Brasileira Geociências, 29: 271-276.

PIMENTEL MM, FUCK RA, JOST H, FERREIRA FILHO CF \& ARAÚJO SM. 2000. The basement of the Brasilia fold belt and the Goiás magmatic arc. In: CORDANI UG, MILANI EJ, THOMAZ FILHO A \& CAMPOS DA. (Eds.). Tectonic Evolution of South America. Rio de Janeiro, DNPM, p. 195-229.

PIMENTEL MM, FERREIRA FILHO CF \& ARMSTRONG RA. 2004. Shrimp U-Pb and Sm-Nd ages of The Niquelândia Layered Complex: Meso- (1.25 Ga) And Neoproterozoic (0.79 Ga) Extensional Events In Central Brazil. Precambrian Research, 132: 133-153.

PIRES ACB. 1990. Statistical characterization of greenstone sequences using magnetic and gamma-ray spectrometric data, Guarinos-Pilar de Goiás, Brazil. Revista Brasileira Geociências, 20: 293-298.

PIRES ACB \& MORAES RAV. 2006. New processing technologies applied do airborne geophysical data: impact on interpretation. Simp. Bras. de Explor. Min. (SIMEXMIN), 2.: 2006, Ouro Preto, MG.

RAINES GL \& BONHAM-CARTERF. 2006. Exploratory spatial modelling: demonstration for Carlin-type deposits, central Nevada, USA, using Arc-SDM. In: HARRIS JR (Ed.). GIS for the Earth Sciences. Geological Association of Canada. Special Publication, 44: 23-52.

RADAMBRASIL PROJETO. 1981. Folha SD. 22 Goiás. Ministério de Minas e Energia. Rio de Janeiro, 640 p (Levantamento de Recursos Naturais, v. 25).

RIVALENTI G, GIRARDI VAV, SINIGOLFI S, ROSSI A \& SIENA F. 1982. The Niquelândia mafic-ultramafic complex of Central Brazil: petrological considerations. Revista Brasileira Geociências, 12: 380-39.

ROEST WR, VERHOEF J \& PILKINGTON M. 1992. Magnetic interpretation using the 3-D analytic signal. Geophysics, 57: 116-125.

SOUZA JO \& LEÃO NETOR. 1998. Programa Levantamentos Geológicos Básicos do Brasil. Projeto Borda Oeste dos Maciços Básico-Ultrabásicos de Niquelândia e Barro Alto. Estado de Goiás, 1:100.000, Brasília: CPRM, 56 pp. 
SOUZA FILHO CR \& CRÓSTA AP. 2003. Geotecnologias aplicadas à Geologia. Revista Brasileira Geociências, 33: 1-4.

TEIXEIRA AA, SILVA AM, PIRES ACB, MORAES RAV \& SOUZA FILHO CR. 2006. Integração e análise de dados aerogeofísicos por meio da aplicação de técnicas de processamento digital de imagens e classificação não supervisionada: 0 exemplo do Greenstone Belt Rio das Velhas, Quadrilátero Ferrífero, MG. Revista Brasileira Geofísica, 24(4): 559-572.

TOU JT \& GONZALEZ RC. 1974. Pattern Recognition Principles, Addison-Wesley Publishing Company, Reading, Massachusetts. 377 pp. ULBRICH HHGJ, ULBRICH MNC, FERREIRA FJF, ALVES LS, GUIMARÃES GB \& FRUCHTING A. 2009. Levantamentos Gamaespectrométricos em Granitos Diferenciados. I: Revisão da Metodologia e do
Comportamento Geoquímico dos Elementos K, Th e U. Geologia USP Serie Científica, 9: 33-53.

UNITED STATES GEOLOGICAL SURVEY. 2000. Shuttle Radar Topography Mission. Available on: <http://srtm.usgs.gov/>. Access on: Feb. $02,2010$.

WILFORD JR, BIERWIRTH PN \& CRAIG MA. 1997. Application of gamma-ray spectrometry in soil/regolith mapping and geomorphology. AGSO Journal of Australian Geology \& Geophysics, 17(2): 201-216.

WILFORD JR, DENT DL, DOWLING T \& BRAATEN R. 2001. Rapid mapping of soils and salt stores. Using airborne radiometrics and digital elevation models. AGSO Research Newsletter, 33-40.

\section{NOTES ABOUT THE AUTHORS}

Inara Oliveira Barbosa. Graduated in Geology from the University of Brasilia (IG/UNB), specializing in GIS (UNB). Holds a MSc in Agricultural Sciences and Ph.D. in Applied Geosciences from the University of Brasilia (UNB). Has experience in Geosciences with emphasis in GIS. Currently, works on the following topics: soils, mining and environment at the National Department of Mineral Production as a specialist in mineral resources/GIS.

Augusto Cesar Bittencourt Pires. Holds a Geology degree from the Universidade Federal do Rio de Janeiro (1968), specialization in Geophysics from the Universidade Federal da Bahia (1971). Has a Ph.D. in Geophysics (1975) and post-doctorate from the Colorado School of Mines (1989). Currently, works as a Professor at the Universidade de Brasilia. Has experience in Geosciences with an emphasis in Geophysics. Topics of interest are: applied geophysics, geophysical mapping, electric resistivity and electrical mapping.

Marilusa Pinto Coelho Lacerda. Holds a Geology degree (1984) and M.Sc. in Geology (Geochemistry) from the Universidade Federal de Minas Gerais (1994). Has a Ph.D. in Agronomy (Soil Science and Plant Nutrition) from the Universidade Federal de Lavras (1998) and specialization in GIS from the Universidade de Brasília (2003). Currently, works as Assistant Professor at the Universidade de Brasília. Has experience in the area of Agronomy - Soil Science, with emphasis in genesis, morphology, survey and soil classification. Acting on the following themes: genesis, survey and soil classification, environmental characterization, conservation of soil and water, pedo-morphological and geological modeling, GIS.

Adriana Chatack Carmelo. Holds a degree in Geology from the Universidade de Brasília (IG/UNB). Pursued graduate studies in the area of Regional Geology (M.Sc.) and Data Processing in Geology and Environmental Analysis (Ph.D.), at the Institute of Geosciences from the UNB. Has professional experience in mineral and groundwater exploration using Applied Geophysics and Data Integration. Currently, holds the position of Assistant Professor (IG-UNB), and teaches the subjects gamma-spectrometric prospecting, physical property of rocks and general geology. 